\title{
"Diólogos" entre Lukács e Pachukanis sobre a crítica ao Direito
}

"Dialogues" between Lukács and Pachukanis on the critic of Law

Vitor Sartori ${ }^{1}$

Resumo: pretendemos trazer à tona a possibilidade de abordar conjuntamente autores díspares como Lukács e Pachukanis. Para tanto, procuraremos mostrar que, na análise do Direito de cada um destes autores, há convergências temáticas que, ao mesmo tempo, colocam-se como pontos de dissonância; isto se mostra, sobretudo, ao se tratar da relação entre Direito e capitalismo, da forma jurídica, da extinção do Direito e da questão da transição ao socialismo. Sobre todos estes temas, é possível buscar uma espécie de embate entre as posições dos autores aqui tratados para, então, desenvolver com mais cuidado, e com fôlego, uma crítica ao Direito.

Palavras-chave: Lukács, Pachukanis, crítica ao Direito, forma jurídica, Direito e capitalismo

Abstract: we intend to bring Pachukanis'and Lukács' theories on Law to a "dialogue". Taking as a departing point their critic of Law, we will show the compatibility, and difference, on a certain level, of the authors' position on Law and Capitalism, the juridical form, the abolition of Law and the transition to Socialism. We intend to explain the possibility and this "dialogue", showing that this may lead to the development of a carefully critic of Law, in which there is still a lot to advance.

1 Professor adjunto da Universidade Federal de Minas Gerais 
Key-words: Lukács, Pachukanis, Critic of Law, juridical form, Law and Capitalism

"A crítica marxista da teoria geral do Direito ainda está em seu início." (PACHUKANIS)

Neste pequeno escrito, trataremos da questão da crítica ao Direito, que vem tendo como grande norte a teoria pachukaniana. Intentaremos isto ao buscar a análise das posições do autor soviético à luz da teoria lukacsiana. Procuraremos mostrar que, ao contrário do que postula Csaba Varga (2012), tendo em conta uma crítica ontológica ao Direito (como aquela que pretende realizar Lukács), tem-se a possibilidade bastante proveitosa de comparar a posição do marxista húngaro com aquela do teórico soviético do Direito. Isto se dá, sobretudo, ao se ter em mente o cuidado que os autores dispensam à questão da gênese e do fenecimento do Direito, que tem como elo mediador a relação existente entre o campo jurídico e as relações de produção capitalistas. Tratando-se de autores bastante importantes para a tradição marxista, uma compreensão cuidadosa da posição de ambos, por si só, já vale a pena. No entanto, acreditamos, aquilo que dizem o autor da Ontologia do ser social e o da Teoria geral do Direito e marxismo pode trazer um espectro mais amplo, tanto para aqueles que se preocupam com a crítica ao Direito, quanto para aqueles que têm em conta a compreensão da especificidade do Direito e sua ligação (ou não ligação) à sociedade capitalista. Outra questão importante trazida à tona está relacionada à "forma jurídica". Trata-se de compreender o real significado desta, suas limitações temporais e a possibilidade de crítica à mesma. Tendo isto em mente, pode-se refletir acerca do real alvo em uma crítica ao Direito.

De início, procuraremos mostrar como que a formação distinta de cada autor faz com que eles tenham enfoques diferentes, mas que, também devido a isso, podem ser trazidos à tona em conjunto ao se 
tratar do Direito. Isto se dá porque afinidades temáticas propiciam uma análise comparativa, que podem ser vistas com cuidado ao enfocar a diferença específica entre a posição de cada autor. Após, passaremos a tratar da posição (e a diferença) específica de cada um quanto a pontos decisivos a um tratamento marxista do Direito, a saber: a relação entre Direito e capitalismo, a questão da forma jurídica e de sua relação com a forma mercantil, a temática da gênese e da extinção do Direito e, por fim, a questão da transição socialista. Trataremos de todas estas questões procurando mostrar confluências (em grande parte temáticas) e dissonâncias entre as posições e teorizações de Lukács e de Pachukanis. Neste percurso, a diferença específica e a concordância entre a posição de cada pensador serão tratadas, não para que se esgote cada tema (o que, claro, precisaria de um trabalho bastante detido - muito mais do que aquele possível no curto espaço que dispomos), mas para que se possa trazer à tona o início de um estudo que pode dar ensejo a diversas pesquisas no futuro. Deste modo, se Pachukanis é inafastável ao se tratar do Direito de modo marxista (Cf. SARTORI, 2015 c), não se pode, de modo algum, tratá-lo como uma ilha de sobriedade dentre aqueles que trataram do Direito a partir de Marx; há também importantes autores marxistas que buscaram compreender o Direito de modo cuidadoso e rigoroso. Este é o caso de Lukács (Cf. SARTORI, 2010), que desenvolveu uma crítica ontológica ao Direito a qual, acreditamos, pode ser vista como uma grande contribuição à crítica marxista ao Direito.

Também por isso, ao se ter em conta a importância da temática e a envergadura da filosofia lukacsiana, pode-se proveitosamente ver em conjunto (sempre destacando as diferenças nos posicionamentos dos autores) a crítica pachukaniana e a lukacsiana à forma jurídica, bem como à relação desta última com a forma mercantil e com a conformação objetiva do trabalho abstrato.

\section{II}

Certamente é preciso muito cuidado ao buscar um diálogo entre a posição de autores díspares e que não tiveram embates explícitos. A 
questão pode ficar ainda mais meandrada quando se tem em mente autores da importância de Pachukanis e de Lukács. Portanto, é preciso bastante cuidado ao tratar de fazer aproximações entre os dois autores - sempre é preciso ver como que as diferenças específicas entre ambos aparecem justamente com a afinidade temática existente entre os autores; uma das razões para tanto se apresenta na convergência e divergência simultâneas das preocupações dos autores: elas convergem uma vez que ambos foram importantes socialistas do século XX e tiveram que conviver (criticando de modo mais ou menos direto) com o "socialismo" característico do seu tempo, aquele que apareceu corporificado na URSS - enquanto Pachukanis teve um destino trágico nos processos de Moscou (Cf. NAVES, 2000), György Lukács foi praticamente reduzido ao ostracismo, seja na Hungria, na Romênia ou na URSS (Cf. TERTULIAN, 2007; MÉSZÁROS, 2002). Ou seja, para os dois pensadores, a solução para as vicissitudes da sociedade de suas épocas estava em uma defesa decidida do socialismo. Isto, entretanto, não impediu que fossem perseguidos justamente por aquilo que parecia ser a corporificação do socialismo no século $\mathrm{XX}$, o "socialismo soviético", o qual, na época staliniana, trouxe um regime policialesco, que não deixaria de se voltar com virulência contra seus opositores (Cf. CLAUDIN, 2013). As preocupações destes autores, por outro lado, divergem em diversos sentidos, uma vez que, enquanto o autor de Teoria geral do Direito e o marxismo dedicou-se quase que exclusivamente ao Direito, o mesmo não se deu com o autor da Ontologia do ser social, para quem a esfera jurídica é uma entre aquelas tratadas. ${ }^{2}$ As divergências também aparecem por razões, por assim dizer, "filológicas", enquanto Pachukanis não teve acesso a obras como os Grundrisse e os Manuscritos econômico-filosóficos, estas últimas foram bastante valorizadas pelo autor húngaro. ${ }^{3}$ Aqui, porém, não podemos tratar dos pontos que afastam estes autores de modo decidido (como a posição sobre a política, sobre a ética e mesmo sobre a natureza das relações de produção soviéticas); o que pretendemos é

2 Para um tratamento da peculiaridade do Direito no pensamento lukacsiano, Cf. SARTORI, 2010, 2014, 2015 a.

3 Para um tratamento de Pachukanis quanto a este ponto, Cf. SARTORI, 2015 c. 
mostrar como que há certas afinidades temáticas que podem fazer com que seja interessante enxergá-los comparativamente sobre determinados aspectos em torno dos quais suas posições aproximam-se tematicamente e entram em conflito concretamente.

O possível embate entre a posição dos autores é propiciado por tanto um como outro terem se dedicado a questões espinhosas, como aquelas acerca do fenecimento do Direito e sobre a particularidade deste último. Interessante notar também que, no que diz respeito à formação dos dois autores em tela, ambos têm proximidades e dissonâncias: tal qual Pachukanis, Lukács teve formação jurídica. (Cf. VARGA, 2012) No entanto, por mais que seja possível, até certo ponto, trazer, sobre o aspecto do Direito, em conjunto a obra destes dois autores em meio à conturbada década de 20 do século passado tendo em conta um diálogo entre História e consciência de classe e Teoria geral do Direito e o marxismo (Cf. ALMEIDA, 2006)4, é bom destacar que a esfera jurídica não é o centro das atenções de Lukács mesmo neste momento, em que a ligação de sua obra com os embates acerca da construção do "socialismo" soviético ${ }^{5}$ sob os auspícios de Lenin são bastante claras. (Cf. LÖWY, 1998) O próprio enfoque dos escritos lukacsianos se modifica bastante com o desenvolvimento posterior de seu pensamento, que se desloca a muitos outros campos, como aque-

4 Para as limitações deste "diálogo", que sequer teria se conformado como tal, Cf. NASCIMENTO, 2007.

5 A própria posição de Lenin aponta para a natureza ainda não socialista da empreitada soviética, que, enquanto o revolucionário russo estava vivo, poderia mais propriamente ser visto como uma espécie de "capitalismo de Estado" (Cf. BETTELHEIM, 1979). A questão passa longe de ser unânime, porém. Para tratar do tema com o cuidado devido, preciso revisitar aqueles que defendem a natureza socialista, mesmo que degenerada, da URSS como Sweezy (SWEEZY, 1963) e aqueles que apontam para uma espécie de sociedade pós-capitalista mas ainda não socialista, como Mészáros (Cf. MÉSZÁROS, 2002). De nossa parte, tendemos a nos aproximar da posição de István Mészáros. Vale apoontar, no entanto que, sobre o período posterior, a posição de Cladin parece bastante acertada sobre o regime da URSS stalinista: "os sentimentos patrióticos vieram em ajuda ao mito, e a vitória [na II Guerra] conferiu-Ihe nova seiva, mas por pouco tempo. O gigantesco «salto industrial», técnico e cultural da Rússia (salto, neste último aspecto, a uma cultura de massa conformista, instrumental) era indiscutível; mas era isso socialismo?" (CLAUDIN, 2013, p. 106) 
le do embate filosófico e estético. ${ }^{6}$ Ou seja, Lukács nunca se coloca como um jurista; Pachukanis nunca se coloca como um filósofo. Assim, os interlocutores destes importantes pensadores, até certo ponto, são bastante diferentes. Porém, é preciso destacar: eles se aproximam e têm preocupações confluentes enquanto pensam, de modo decidido, uma crítica à sociedade capitalista e ao Direito. Também têm como interlocutores, de modo mais geral, todos aqueles envolvidos no projeto de transformação socialista da sociedade. No entanto, o enfoque destes autores não deixa de ser distinto, o que torna impossível um verdadeiro "diálogo" entre eles. O máximo que se pode fazer é mostrar como estes autores pensaram questões bastante importantes que, neste aspecto, podem os aproximar ao mesmo tempo em que os afastam: nisto consiste o embate que aqui propomos.

Trazer explicitamente ao debate intelectual e político o tema do Direito (como pretendemos fazer aqui) por meio de autores deste relevo pode ser muito proveitoso, porém. Ambos autores, por exemplo, são explícitos ao enfatizar a necessidade do fenecimento do Direito em uma sociedade socialista. Só isso, em verdade, já justifica um tratamento conjunto. No entanto, ainda é possível destacar algo mais: fora o esforço de Silvio Luís de Almeida $(2006)^{7}$, que se voltou ao estudo de História e consciência de classe, foram poucos que tentaram alguma aproximação entre as posições destes autores. Em verdade, em uma das únicas obras em que se pretende tratar da concepção de Direito de Lukács, O lugar do Direito na concepção de mundo de Lukács, Varga justamente enxerga Pachukanis como alguém imbuído de reducionismo econômico e de um determinismo inaceitáveis. (Cf. VARGA, 2012) Ou seja, tal trabalho (abordar conjuntamente Lukács e Pachukanis, ao mesmo tempo em que se tem em mente o cará-

6 Interessante notar que estes campos eram tratados de modo bastante abundante na obra pré-marxista de Lukács, influenciada por distintas formas de aproximação com o neokantismo e com o hegelianismo, além de certa aproximação com Kierkgaard (Cf. MACHADO, 2003). Neste sentido, o afastamento quanto a Pachukanis é ainda mais claro.

7 É preciso destacar que o próprio Almeida, agora sob clara influência althusseriana, trata de enxergar como impossível tal empreitada, a qual, no momento, parece-lhe ser mais possível por meio de uma leitura conjunta de Althusser e Pachukanis, especialmente no que toca a crítica à noção de sujeito. Cf. ALMEIDA, 2016. 
ter bastante mediado da empreitada) está longe de ter sido realizado. Por vezes, isto foi visto como impossível, como em Csaba Varga, que tende a afastar Pachukanis de modo bastante apressado, por vezes, dando um tom demasiadamente jurídico ao pensamento lukacsiano (Cf. SARTORI, 2015 d); noutros momentos, o tema foi tratado somente nos pontos em que os autores se distanciam de modo decidido, como ao se tratar da relação entre ética e moral (Cf. SARTORI, 2015 a) de tal maneira que ver de modo mais nuançado as posições dos autores pode ser bastante proveitoso tanto para aqueles que estudam o jurista soviético quanto aos que estudam o marxista húngaro (e, claro, aqueles que compartilhem da posição socialista destes dois importantes autores). Aqui, procuraremos realizar este trabalho tendo em conta a obra madura de Lukács, principalmente, sua Ontologia do ser social, a qual, juntamente com a Estética, oferece um tratamento cuidadoso acerca da peculiaridade e especificidade da esfera jurídica.

Uma última razão que pode ser apontada para que se tenha em mente em conjunto tais autores é a seguinte: no Brasil, quando se trata de Direito e marxismo, há uma clara hegemonia althuseriana. Ela decorre, em grande parte, da envergadura do pensamento de Márcio Bilharinho Naves, pensamento este que, a partir de uma posição althusseriana, abre espaço para um debate importante no campo dos críticos ao Direito. (Cf. SARTORI, 2015 b) No entanto, com ela, também vem, não raro, uma compreensão do marxismo que, em definitivo, fecha as portas para o pensamento de György Lukács, autor este que, com aqueles marxistas que Althusser rechaça, traria - segundo o autor de Por Marx - posições "contaminadas por um hegelianismo vergonhoso”. (ALTHUSSER, 1979, p. 100) Trata-se de uma posição que, em nossa opinião, não atenta suficientemente para a obra lukacsiana e não tem em mente as inúmeras críticas que Lukács tece a Hegel tanto em O jovem Hegel como na Ontologia do ser social de modo que, também por isso, um estudo cuidadoso da obra lukacasiana pode ajudar em muito na crítica ao Direito. ${ }^{8}$

8 Aqui não podemos tratar do embate possível, e necessário, entre as posições de Althusser e de Lukács. Vale destacar, porém, que alguns, como Tertulian, enfocando a ênfase que cada autor dá à autonomia relativa das distintas esferas do ser social, bem como a crítica de 


\section{III}

A tarefa de apreender a especificidade do Direito a partir de Lukács e (ou) Pachukanis também oferece outra grande dificuldade: o marxista soviético diz sobre seu principal trabalho que "o presente trabalho não pretende ser de jeito nenhum fio de Ariadne marxista no domínio da teoria geral do Direito; ao contrário, pois em grande parte foi escrito objetivando o esclarecimento pessoal." (PACHUKANIS, 1989, p. 1) Ou seja, sua grande obra, que, efetivamente, veio a servir (e ainda serve) de "fio de Ariadne marxista" no que toca a compreensão da esfera jurídica, segundo o próprio autor, não teve, nem poderia ter, este uso. Há de se reconhecer a modéstia do autor, certamente. Sua obra, não obstante seu pequeno tamanho, é, no que toca o Direito, muito maior do que parece sugerir Pachukanis (Cf. NAVES, 2000); no entanto, tendo-se em mente que parte substancial da obra de Marx ainda não havia sido tornada pública à época de Teoria geral do Direito e o marxismo, não se pode, hoje, deixar de lado este fato ao tratar da envergadura da obra pachukaniana (Cf. SARTORI, 2015 c). Ao se ter em mente o trabalho de Lukács, e seu tratamento sobre o Direito, a situação não é muito melhor, porém. De certo modo, tem-se o problema diametralmente oposto: o autor, tendo ao seu dispor obras que Pachukanis não dispunha (Grundrisse, Manuscritos econômico-filosóficos, principalmente), e ao buscar o "renascimento do marxismo" (Cf. LUKÁCS, 2010), procura muito mais situar o marxismo, tanto social quanto intelectualmente, em meio à cultura ocidental, não tendo como foco a análise exaustiva do Direito.

Ao dizer que, ao tratar do Direito, e da relação entre o fático e o jurídico, "a intenção era apenas dar um vislumbre dos contornos mais gerais desse complexo, visando apreender os princípios do seu funcionamento" (LUKÁCS, 2013, p. 237), o autor húngaro deixa claro que somente procurou trazer os "contornos mais gerais" do complexo jurídico. Este último é visto por Lukács somente ao passo que é essencial

ambos a Hegel (!) aproxima as posições destes autores sob diversos aspectos. Isto, claro, dá-se reconhecendo a impossibilidade de conciliá-los e as influências diametralmente opostas do pensamento de cada um dos autores. Cf. TERTULIAN, 2016. 
para tratar da reprodução social (principalmente na sociedade capitalista - voltaremos ao tema posteriormente) de tal modo que trata com cuidado daquilo que Pachukanis não aborda detidamente (dos aspectos gerais da posição marxista, tendo em conta a especificidade de cada esfera do ser social). Ao mesmo tempo, sua análise do Direito é muito menos exaustiva que a do autor soviético. Aqueles que pretendem tratar da esfera jurídica com base nestes autores, pois, não têm uma tarefa fácil. Podem ter excelentes pontos de partida, mas não uma concepção já elaborada em suas minúcias, e que careça de uma complementação: trata-se de autores que, no que diz respeito ao Direito, precisam ser compreendidos com muito cuidado (o que não é nada fácil, diga-se de passagem), ao mesmo tempo em que precisam ser vistos como pontos de partida, e não de chegada. Neste ponto, pode-se citar Pachukanis, que diz que sua obra "na melhor das hipóteses, devia apenas servir de estímulo". (PACHUKANIS, 1989, p. 1) ${ }^{9}$

Sobre este ponto, novamente, é necessário dizer que ainda há muito a se avançar. Contribuições neste sentido vêm aparecendo no Brasil com uma perspectiva claramente althusseriana, como em Márcio Naves $(2000,2014)$ e em Celso Kashiura $(2009,2014)$ ou com o trabaIho conjunto de ambos (2011). Para estes autores, há clareza acerca de suas perspectivas filosóficas, certamente. No entanto, há de se admitir que muitos dos que os citam não necessariamente têm consciência acerca da filiação destes autores dentro da filosofia marxista, tratando-se de uma abordagem que, nos âmbitos jurídicos, pode ser vista como sinônimo de abordagem marxista. Isto, acreditamos, pode levar, a certo fechamento no que diz respeito ao diálogo e ao embate honesto entre os marxistas que tratam do Direito. Eles, claro, não necessariamente concordarão com as premissas de Althusser, mas, até certo ponto, obrigatoriamente, precisam ter como referência o pensamento pachukaniano. (Cf. SARTORI, 2015 c) Isto se dá pela envergadura do pensador soviético no que toca a esfera jurídica, como já

9 Na continuação, diz o autor ainda: "isto significa diz que é muito insuficiente a literatura marxista referente à teoria geral do Direito." (PACHUKANIS, 1989, p. 1) aqui não podemos tratar da questão, mas deve-se apontar que a aceitação, mesmo que crítica, de uma "teoria geral do Direito" pode ser bastante questionada. (Cf. SARTORI, 2015 c) 
mencionamos. No entanto, é interessante notar que em algumas passagens de Teoria geral do Direito e marxismo o autor explicitamente toma como referência Sobre a questão judaica, obra de Marx de 1843 e rechaçada, nos meios althusserianos, como ainda marcada por uma concepção, para dizer o mínimo, problemática. ${ }^{10}$ (Cf. NAVES, 2014) Destacamos isto pela seguinte razão: se Pachukanis não desenvolveu explicita e sistematicamente sua concepção mais geral, principalmente em torno de questões, por assim dizer, "filosóficas", é possível apontar que, ao menos no Brasil, isto vem sendo "suprido" por uma perceptiva que tem como ponto de partida o pensamento de Louis Althusser. Claro que isto se dá com diversas mediações, já que não é possível simplesmente "complementar" um grande autor com outro; no entanto, é bastante clara a relação estabelecida no Brasil entre althusserianismo e a posição pachukaniana (principalmente, ao se ter em conta a afinidade existente entre ambos ao estabelecer uma crítica à noção de sujeito). De nossa parte, acreditamos que a tematização conjunta de Pachukanis e Althusser (por mais que pudesse ser mais explícita) ${ }^{11}$, pode estar rendendo frutos bastante interessantes. O mesmo, porém, não se dá quando se tem em mente a possibilidade de tematização de Lukács e o autor da Teoria geral do Direito e marxismo, sendo nossa tarefa dar os primeiros passos neste sentido.

\section{IV}

Talvez, um primeiro tema a ser tratado ao se ter em conta a questão diz respeito à especificidade capitalista do Direito, defendida pelo autor da Teoria geral do Direito e o marxismo. Isto aparece explicitamente em Pachukanis ao afirmar "reconhecer a existência do Direito somente na sociedade burguesa”. (PACHUKANIS, 1989, p. 9) Ele, po-

10 Ter-se-ia, segundo o autor que, “uma 'censura epistemológica' intervém, sem nenhum equívoco, na obra de Marx. (ALTHUSSER, 1979, p. 23) Lukács, por sua vez, aponta que "certamente é uma estupidez historiográfica insistir sobre a contraposição entre jovem Marx e o Marx maduro." (LUKÁCS, 1969, p. 56)

11 Talvez este caráter "mais explícito" esteja começando a vir à tona, ao se ter em conta a problematização da fundamentação da crítica ao Direito e da subjetividade jurídica. (Cf. ALMEIDA, 2016) 
rém, depara-se com críticas com as quais foi obrigado a concordar, em suas palavras, "com reservas precisas" (PACHUKANIS, 1989, p. 9), admitindo formas embrionárias de Direito em sociedades pré-capitalistas (algo que, é bom destacar, é bastante criticado por Márcio Naves (2014)). ${ }^{12}$ Veja-se o que diz o marxista soviético:

\begin{abstract}
Efetivamente, tenho afirmado, e continuo a afirmar, que as relações dos produtores de mercadorias entre si engendram a mais desenvolvida, universal e acabada mediação jurídica, e que, por conseguinte, toda a teoria geral do Direito e toda a jurisprudência 'pura'13 não são outra coisa senão a descrição unilateral, que abstrai de todas as outras condições das relações dos homens que aparecem no mercado como proprietários de mercadorias. Mas, uma forma desenvolvida e acabada não exclui formas embrionárias e rudimentares; pelo contrário, pressupõem-nas. (PACHUKANIS, 1989, p. 9)
\end{abstract}

A primeira questão a se notar é que, por mais que a análise do autor não seja "circulacionista", sua ênfase na esfera de circulação de mercadorias é notável. Para ele, "a gênese da forma jurídica está por se encontrar nas relações de troca”. (PACHUKANIS, 1989, p. 8) Alguns, a partir disso, indicaram descaso do autor quanto à reprodução ampliada do capital (Cf. CASALINO, 2011), tendo-se, em Pachukanis, uma visão equivocada quanto ao real funcionamento do capitalismo.

Tal posição, porém, como fica claro pela passagem, não pode ser completamente verdadeira. Trata-se das "relações dos produtores de mercadorias entre si”, o que faz com que seja necessário reconhecer a íntima relação entre a esfera da circulação e da produção no marxista soviético. A ênfase dada à figura dos proprietários de mercadorias (uma figura jurídica) é bastante visível também, tendo-se a

12 Esta questão aparece como algo central na literatura althusseriana: "não apenas o capitalismo exige uma determinada modalidade de direito, mas principalmente, que a forma jurídica é capitalismo." (KASHIURA, 2009, p. 117) Com próximo, Mascaro também aponta que "o capitalismo, assim, é necessariamente jurídico. Os modos de produção anteriores não." (MASCARO, 2009, p. 113)

13 Vale destacar aqui a noção de "pureza" que acompanha a crítica pachukaniana. Para uma posição sobre a relação do autor com a "teoria geral do Direito", Cf. SARTORI, 2015 c) 
troca equivalente (e, portanto, a lei do valor) como algo indissociável do modo como se conforma a esfera jurídica efetivamente. Deste modo, a partir disto, para o autor, "não deixa de existir um vínculo interno indissociável entre as categorias da economia mercantil, e monetária e a própria forma jurídica". (PACHUKANIS, 1989, p. 7) Ou seja, a "forma jurídica" - sua própria conformação em sua especificidade, portanto - seria inseparável da esfera de circulação de mercadorias (a "economia mercantil"). De tal maneira, a ligação entre Direito e capitalismo teria como termo mediador a mercadoria (mais precisamente, a forma-mercadoria). E ela somente apareceria em sua efetividade ao adquirir contornos universais, possíveis em uma sociedade em que as relações sociais de produção têm como termo mediador universal as mercadorias.

Ou seja, segundo Pachukanis, o Direito "propriamente dito" não se liga diretamente à mercadoria, mas a sua universalização enquanto mediador social. A especifidade do Direito estaria ligada a uma conformação específica das relações sociais de produção: aquela que propicia uma esfera de circulação homogenizadora e que abrange, em um ímpeto totalizador, potencialmente, a totalidade das relações sociais. E isto somente aconteceria na sociedade capitalista.

Isto se daria, sobretudo, ao se ter em conta a conformação da relação-capital ${ }^{14}$, a qual torna a venda da mercadoria força de trabalho central à sociabilidade de uma época, uma vez que tem-se a expropriação dos meios de produção como fato conformativo da sociedade capitalista. (Cf. MARX, 1988) O que nos é central sobre este ponto é: aquilo que se apresenta de imediato no cotidiano capitalista - a venda e compra de mercadorias, e da mercadoria força de trabalho em especial - aparece como algo essencial à própria conformação do

14 Com isso, tem-se a ligação necessária entre a circulação e a produção já que "a relaçãocapital pressupõe a separação entre os trabalhadores e a propriedade das condições de realização do trabalho. Tão logo a produção capitalista se apoie sob os próprios pés, não apenas conserva tal separação, mas a reproduz em escala sempre crescente. Portanto, o processo que cria a relação-capital não pode ser outra coisa que não o processo de separação entre o trabalhador e a propriedade das suas condições de trabalho, um processo que por um lado transforma os meios sociais de subsistência e de produção em capital, por outro, os produtores imediatos em operários assalariados." (MARX, 1988, p. 252) 
Direito, para que se use o tom de Pachukanis, à "forma jurídica". Segundo o marxista soviético, isto tem consigo um processo de universalização das relações de troca de mercadorias somente presente na sociedade capitalista. Isto faria com que, efetivamente, só se pudesse falar de Direito nas sociedades capitalistas: "na sociedade burguesa a forma jurídica, em oposição ao que ocorre nas sociedades edificadas sobre a escravatura e a servidão, adquire uma significação universal." (PACHUKANIS, 1989, p. 9) Percebe-se, pois: a "significação universal" da forma jurídica é tomada pelo autor soviético como sinônimo de Direito "propriamente dito". Parece mesmo haver certa distinção entre o Direito e a forma jurídica ${ }^{15}$ : de acordo com aquilo que colocamos sobre Pachukanis, aonde há forma jurídica, poderia haver "formas embrionárias e rudimentares" de Direito, ao passo que somente com a universalização desta forma, com a sua "significação universal", a esfera jurídica estaria presente em sua especificidade tendo-se o Direito "propriamente dito".

Esta colocação do autor pode ser essencial à sua posição pois ela torna possível falar de "formas embrionárias" ou "rudimentares" de Direito. Parece-nos que só ela permite que se compreenda como que, por mais imprecisa que sejam expressões como "Direito romano", "Direito medieval", elas não sejam um simples disparate. Tratar-se-ia, caso se siga Pachukanis, de um uso impreciso da noção de Direito, certamente. O Direito, em verdade, pressuporia a forma jurídica já universalizada $^{16}$; mas o uso referido da noção não expressaria algo totalmente alheio ao campo jurídico já que, nas sociedades anteriores à capitalista, haveria relações mercantis e, portanto, segundo o autor soviético, de certo modo, relações mediadas pela forma jurídica. Se seguirmos este raciocínio, pode-se dizer que esta forma não é explicitada em sua especificidade anteriormente à vigência universal do

15 Que saibamos, este ponto ainda precisa ser estudado por aqueles que se dedicam à obra de Pachukanis.

16 Aponta Naves sobre Pachukanis que "só na sociedade burguesa a forma jurídica alcança o seu mais alto grau de abstração, o que permite que ela se torne realmente verdadeira apenas no interior desse modo de produção, da mesma maneira que o trabalho só se torna trabalho realmente abstrato na sociedade capitalista." (NAVES, 2000, p. 50) 
modo de produção capitalista, uma vez que "as relações dos produtores de mercadorias entre si engendram a mais desenvolvida, universal e acabada mediação jurídica". Com isso, ter-se-ia mediações jurídicas que não se conformem desta maneira "universal", mas de modo somente insipiente, "embrionário", "rudimentar". Pachukanis expressa, portanto, ao mesmo tempo, aquilo que caracteriza o Direito e o modo pelo qual este chegou a ser o que é no presente, atentando-se ao caráter processual da autonomização das esferas do ser social.

Para o autor soviético, justamente este caráter processual, e histórico, seria "esquecido" por aqueles que normalmente se dedicam ao estudo do Direito. Ao hipostasiar as relações jurídicas, "toda a teoria geral do Direito e toda a jurisprudência 'pura' não são outra coisa senão a descrição unilateral, que abstrai de todas as outras condições das relações dos homens que aparecem no mercado como proprietários de mercadorias." Assim, ao não se tratar explicitamente da base real sobre a qual se conforma o Direito, ter-se-ia justamente unilateralidades gritantes. ${ }^{17}$ Ao se ater à superfície das relações sociais capitalistas e ao naturalizar a esfera de circulação mercantil, aqueles que se colocam como juristas e como jurisconsultos trariam, no máximo, uma "descrição unilateral" da própria base sobre a qual se soergue o Direito. Deixariam de lado justamente o essencial. Ou seja, os últimos a entender efetivamente o ser social do Direito seriam os próprios envolvidos na prática jurídica cotidiana. Neste sentido, já aqui, é possível notar que, para ser coerente com seu projeto socialista, Pachukanis precisa realizar uma crítica não só às relações de produção capitalistas - tem-se como necessária uma crítica ao Direito. Ele não busca, nem pode buscar, uma esfera jurídica "socialista", mas a supressão mesma da esfera jurídica, e da forma jurídica.

17 Vale lembrar de duas importantes passagens de Marx, na primeira, ele diz que "toda concepção histórica existente até então ou tem deixado completamente desconsiderada essa base real da história, ou a tem considerado apenas como algo acessório, fora de toda e qualquer conexão com o fluxo histórico." (MARX; ENGELS, 2007, p. 43) Já na segunda, ele é explícito sobre a relação entre o Direito e as distintas esferas do ser social: "o Direito nunca pode ultrapassar a forma econômica e o desenvolvimento cultural, por ela condicionado, da sociedade". (MARX, 2010, p. 31) 


\section{V}

Ainda sobre o tema da ligação entre capitalismo e Direito, vale a pena confrontar a posição pachukaniana com a lukacsiana. O primeiro ponto a ser trazido é o uso distinto da noção de Direito em ambos os autores: certamente, o uso lukacsiano poderia ser criticado por $\mathrm{Pa}$ chukanis, já que o primeiro se refere, por vezes, ao "Direito romano", ao "Direito do medievo" (Cf. LUKÁCS, 2013). No entanto, ao mesmo tempo, é preciso notar que há certa confluência na análise dos autores sobre a especificidade do Direito, de modo que é preciso ter cuidado na análise da questão. ${ }^{18}$ Vejamos o que se diz na Ontologia do ser social sobre a gênese e o desenvolvimento da esfera jurídica:

Por mais que, naquelas condições primitivas, as pessoas singulares, em situações vitais, tomavam espontaneamente decisões em média mais parecidas do que posteriormente, por mais que, na igualdade de interesses que naquele tempo ainda predominava, tenha havido menos razões objetivas para resoluções contrárias, sem dúvida houve casos de fracasso individual, contra os quais a comunidade precisou se proteger. Assim, teve de surgir uma espécie de sistema judicial para a ordem socialmente necessária, por exemplo, no caso de tais cooperações, muito mais no caso de contendas armadas; porém, ainda era totalmente supérfluo implementar uma divisão social do trabalho de tipo próprio para esse fim; os caciques, os caçadores experientes, guerreiros etc., os anciãos podiam cumprir, entre outras, também essa função, cujo conteúdo e cuja forma já estavam traçados em conformidade com a tradição, a partir de experiências reunidas durante longo tempo. Só quando a escravidão instaurou a primeira divisão de classes na sociedade, só quando o intercâmbio de mercadorias, o comércio, a usura etc. introduziram, ao lado da relação "senhor-escravo", ainda outros antagonismos sociais (credores e devedores etc.), é que as controvér-

18 Alysson Mascaro critica Lukács justamente sobre este ponto: “Lukács, na Ontologia, não chega às minúcias de Pachukanis, que desenvolve com muita ênfase a identificação da especificidade do direito à forma mercantil." (MASCARO, 2012, p. 547) Veremos, porém, que a crítica não resiste a uma análise detida da Ontologia do ser social. 
sias que daí surgiram tiveram de ser socialmente reguladas e, para satisfazer essa necessidade, foi surgindo gradativamente o sistema judicial conscientemente posto, não mais meramente transmitido em conformidade com a tradição. A história nos ensina também que foi só num tempo relativamente tardio que até mesmo essas necessidades adquiriram uma figura própria na divisão social do trabalho, na forma de um estrato particular de juristas, aos quais foi atribuída como especialidade a regulação desse complexo de problemas. (LUKÁCS, 2013, p. 230)

Lukács liga a emergência da regulamentação jurídica à oposição entre os interesses individuais em meio às relações cotidianas. Tem-se justamente algo que rompe com a "igualdade de interesses" existente somente em "condições primitivas" quando se tratava de "situações vitais"; para tratar de casos em que houvesse um desvio quanto a esta "igualdade" e quanto à estrutura social de uma ordem, em condições específicas, "socialmente necessária", seria preciso alguma regulamentação: tratar-se-ia de "uma espécie de sistema judicial". E os termos do autor são bastante gerais e, certamente, caso ficassem neste grau de concretude, seriam extremamente criticáveis.

Aquilo que se nota de imediato, porém, é o cuidado que tem o autor húngaro ao tratar da questão. Sua posição é bastante distinta daquela segundo a qual "aonde há sociedade, há Direito" (Cf. SARTORI, 2010), tendo-se por essencial a questão da gênese a do necessário fenecimento da esfera do Direito: "os limites histórico-sociais da gênese e do fenecimento da esfera do direito estão determinados fundamentalmente como limites temporais." (LUKÁCS, 2013, p. 244) Por conseguinte, não é de se estranhar que o autor húngaro fale de "uma espécie de sistema judicial", e não do Direito conformado em sua especificidade. Este último, segundo Lukács, supõe justamente a clara delimitação que se pode estabelecer entre a ética, a moral o Direito..$^{19}$ Ou seja,

19 Aqui, não poderemos tratar da diferença específica entre estas esferas. Neste ponto, Lukács distancia-se bastante de Pachukanis (Cf. SARTORI, 2015 a), chegando a afirmar, ao contrário do autor, a centralidade que pode adquirir a ética ao se tratar de modo marxista do Direito: "pode-se afirmar que a ética constitui no sistema das práticas humanas um centro mediador entre o Direito puramente objetivo e a moralidade puramente subjetiva." (LUKÁCS, 1966, p. 220) Tertulian chega mesmo a apontar sobre Ontologia que "Lukács 
tem-se como suposta a divergência entre o interesse individual e o de uma ordem constituída; no entanto, somente este pressuposto não traz consigo todas as determinações históricas do Direito. Diz o autor na Ontologia algo que pode ser bastante esclarecedor sobre a especificidade do campo jurídico:

Quando os antagonismos sociais já adquiriram formas mais mediadas, reduzir a regulamentação do agir ao puro uso da força significaria chegar, sem mais, à destruição da sociedade. Neste ponto deve assumir o predomínio aquela complicada unidade de força explícita e força disfarçada, revestida com as vestes da lei, que ganha forma na esfera jurídica. [...] E, na realidade, o Direito na pólis grega e também na república romana tem um significado todo particular. É o portador, o centro espiritual da atividade humana em geral. Tudo aquilo que, logo após, se articulará na moral e até na ética, na concepção clássica da pólis é ainda totalmente ligado ao Estado, ainda completamente idêntico ao Direito. (LUKÁCS, 1981, p. XCII)

A forma mais ou menos "imediata" que os conflitos sociais têm em "condições primitivas", em que começa a se delinear o antagonismo entre o interesse individual e o da "ordem socialmente necessária", logo dariam lugar a "antagonismos sociais" - centrais na caracterização do Direito. Estes últimos, segundo Lukács, somente são pensáveis tendo em conta o antagonismo entre classes sociais e, em verdade, trazem consigo, com o desenvolvimento social, um momento em que "reduzir a regulamentação do agir ao puro uso da força significaria chegar, sem mais, à destruição da sociedade." O Direito, assim, aparece em Lukács como algo inseparável do uso da força e do afastamento deste último. (Cf. SARTORI, 2010) E, assim, aquilo que ganha forma na esfera jurídica são relações sociais que trazem consigo uma "complicada unidade de força explícita e força disfarçada, revestida com as vestes

ai propõe restituir à política, ao Direito, à moralidade, a ética o lugar que lhes corresponde na topografia da sociedade, demonstrando que a densidade e a complexidade do tecido social excluem toda codificação a partir de normas abstratas." (TERTULIAN, 2007, p. 39) Ou seja, tratar da diferença e do papel que cabe a cada uma destas esferas do ser social seria, inclusive, essencial à crítica do presente. 
da lei." O autor da Ontologia, pois, mostra como que esta "complicada unidade" é que subjaz em qualquer concepção de Direito que possa ser coerente com uma concepção materialista. Deste modo, Lukács traz uma delimitação bastante geral nesta caracterização da noção de Direito. No entanto, não é só: o modo como, ontogeneticamente (Cf. TERTULIAN, 2009), Lukács vai caracterizando o campo jurídico faz com que, simultaneamente, o autor explicite a autonomia relativa deste e a sua indissociabilidade quanto ao desenvolvimento multifacetado da totalidade social. Ou seja, para chegar à especificidade do Direito, o marxista húngaro mostra como esta esfera tem alguma proximidade com fenômenos que emergiram no devir social, ao mesmo tempo que se afasta da ética, da moral e de outras formas de normatividade.

Ter cuidado com o uso da linguagem lukacsiano, novamente, é importante. Tal como antes havia apontado a existência de "uma espécie de sistema judicial", agora, aponta o autor que somente se pode falar do "Direito na pólis grega e também na república romana" ao se ter em mente que este tem "um significado todo particular". E, aqui, novamente, são claras as ressalvas. Isto se daria porque haveria certa indistinção entre importantes esferas do ser social. Isto se daria já que a "atividade humana" presente na época parecia ter por central o Direito justamente por este ainda ser "completamente idêntico" ao que "se articulará na moral e até na ética". Ou seja, ao se falar de Direito na Grécia e na Roma antigas seria preciso perceber: a especificidade deste ainda não poderia aparecer já que haveria certa confusão entre as esferas da moral, da ética e do Direito. Neste sentido, é preciso que se note um cuidado com o uso da noção de Direito que é compartilhado por Lukács e por Pachukanis. Por mais que o último não fale de Direito nestes casos, mas de algo "embrionário" e "rudimentar", há uma clara convergência (que, claro, não pode ser exagerada) ao se perceber que ambos os autores marxistas são bastante cautelosos ao tratar da especificidade desta esfera do ser social. A questão ganha ainda mais relevo quando o autor da Ontologia destaca que, mesmo com uma "espécie de sistema judicial", não se tem sempre a conformação específica de uma esfera do ser social diferenciada efetivamente ao se falar do Direito: "ainda era totalmente supérfluo implementar uma 
divisão social do trabalho de tipo próprio para esse fim." E, claro, sem uma "divisão do trabalho de tipo próprio" não se pode propriamente falar de uma esfera do ser social que explicite a especificidade do Direito. Este último, na antiguidade, colocar-se-ia enquanto "portador" e "centro espiritual" da atividade humana, não tanto devido a sua especificidade, mas devido à sua indistinção quanto às esferas da ética e da moral, as quais, modernamente, enquanto esferas do ser social, separar-se-iam de modo claro do Direito e da "divisão do trabalho de tipo próprio" deste.

Neste momento inicial, ter-se-ia algo que sequer precisava de juristas (podendo ser exercido por "caciques", "caçadores experientes", "anciãos", "guerreiros", e outros), não se tendo aquilo que só apareceria muito mais tarde e tomasse a "forma de um estrato particular de juristas, aos quais foi atribuída como especialidade a regulação desse complexo de problemas." ${ }^{20}$ No que, neste ponto, surgem algumas questões centrais ao que aqui tratamos: qual seria o nexo que faria com que isto fosse necessário? A partir de quando começa a se delinear esta especialização na divisão social do trabalho? Quando é realmente necessário "um estrado particular de juristas"?

A resposta lukacsiana é bastante interessante quando temos em conta o tratamento conjunto deste autor com alguém como Pachukanis. Segundo o marxista húngaro, escapa-se de "uma espécie de sistema judicial" rumo a um "sistema judicial conscientemente posto, não mais meramente transmitido em conformidade com a tradição" somente com as sociedades classistas. Tem-se um processo de desenvolvimento em que a especificidade do Direito vai se tornando mais explícita enquanto, em meio aos conflitos sociais, as esferas do ser social vão se autonomizando. (Cf. SARTORI, 2010) E, deste modo, Lukács traz uma determinação mais precisa de seu conceito de Direito. No entanto, a questão se delineia de modo ainda mais cuidadoso ao passo que

20 Aponta Lukács que "assim, nesse caso, um estrato particular de homens se torna portador social de um complexo particular, em relação ao qual a divisão social do trabalho se desdobra. Nesse tocante, é preciso mencionar de imediato que, simultaneamente com o surgimento da esfera judicial na vida social, um grupo de homens recebe a incumbência social de impor pela força as metas desse complexo." (LUKÁCS, 2013, p. 230) 
o autor diz que "só quando o intercâmbio de mercadorias, o comércio, a usura etc. introduziram, ao lado da relação 'senhor-escravo', ainda outros antagonismos sociais (credores e devedores etc.)" se tem este sistema. Ou seja, tal qual Pachukanis, o autor trata de relacionar o Direito à esfera de circulação de mercadorias. E, neste sentido, há uma proximidade bastante grande entre estes dois importantes marxistas. É certo que esta proximidade não pode ser exagerada: diferentemente do autor de Teoria geral do Direito e marxismo, o autor da Ontologia não liga o Direito somente ao capitalismo. Lukács tem em conta que a circulação mercantil não é sinônima de sociedade capitalista, ligando a esfera jurídica, que vai se conformando em sua especificidade, à primeira, e não à segunda. Seria possível, assim, falar em formas de Direito pré-capitalistas, mesmo que, nestas, por vezes, a esfera ainda apareça como algo acoplado a outras esferas sociais, como a ética, a moral, a religião, entre outras. Portanto, aquilo que efetivamente caracteriza o Direito aparece de modo mais claro quando estas esferas estão autonomizadas, ao mesmo tempo em que, em épocas anteriores, com algum cuidado, seria possível se falar de Direito.

A distinção pachukaniana entre Direito "propriamente dito" e a forma jurídica está ausente em Lukács. Nesta esteira, o autor húngaro não fala de "rudimentos" ou de algo "embrionário", mas de uma forma de regulação e mediação de um sistema judicial, que "foi surgindo gradativamente" e que, em verdade, pode ser chamado de Direito. Ou seja, o modo pelo qual o sistema judicial foi surgindo aparece com um duplo aspecto no autor da Ontologia: de um lado, tendo-se em conta a autonomização das esferas do ser social (Cf. SARTORI, 2010), que leva a uma necessária distinção entre moral, ética e Direito (Cf. SARTORI, 2015 a); doutro lado, tem-se a mediação da esfera de circulação de mercadorias e de seu desenvolvimento. E, aqui, é preciso destacar: tal qual para Pachukanis, o maior desenvolvimento desta esfera se dá justamente na sociedade capitalista. Ou seja, a abordagem que os autores dão ao tema se aproximam bastante em alguns pontos. Tem-se, certamente, uma diferença de nomenclatura quando Lukács fala do Direito que ainda não está explicitamente conformado em sua especificidade e quando Pachukanis fala de algo 
embrionário. No entanto, o cuidado ao se apreender a especificidade desta esfera do ser social é evidente em ambos autores e, neste sentido, também sobre este aspecto, pode ser interessante um estudo conjunto de Lukács e Pachukanis.

\section{VI}

Tal aproximação seria bastante unilateral se não passasse por aquilo que é central na análise pachukaniana: a questão da forma jurídica, indissociável da mercantil. Sobre tal ponto, é preciso que se atente ao fato de Lukács haver dito explicitamente ser imperativo "afirmar, teórica e praticamente, a prioridade do conteúdo político-social em relação à forma jurídica." (LUKÁCS, 2007, p. 57) Ou seja, a questão não é ausente no autor húngaro. Porém, ela também não é central do mesmo modo como no autor da Teoria geral do Direito e o marxismo. Na passagem lukacsiana há uma clara crítica à forma jurídica, que deveria ser colocada "teórica e praticamente" como algo inseparável do "conteúdo político social". Porém, é preciso que se note que a equação direta colocada por Pachukanis entre forma jurídica e forma mercantil não se encontra no autor da Ontologia, mesmo que este afirme que o desenvolvimento gradual do sistema jurídico passe necessariamente pelo desenvolvimento complexo da circulação de mercadorias. ${ }^{21}$ Neste

21 A seguinte passagem de Lukács é bastante interessante sobre este aspecto: "Num primeiro momento, eles são considerados no âmbito do direito privado - neste, a conexão entre direito e intercâmbio de mercadorias é diretamente perceptível. Obviamente também nesse caso o desenvolvimento é desigual. O fato de que, por exemplo, na Idade Média, o poder estatal fosse descentralizado, de que indivíduos pudessem dispor não só de armas, mas também de séquitos maiores ou menores de homens armados, fazia com que, naqueles tempos, a imposição de um decreto emanado do direito estatal muitas vezes se tornasse uma questão de combate aberto entre o poder central e a resistência contra ele. A socialização da sociedade impôs nesse ponto formas de transição tão paradoxais, que para certas épocas o conteúdo do direito passa a ser avaliar em que casos tais resistências são juridicamente válidas esmiuçar as contradições dessas teorias; elas decorrem principalmente da problemática da passagem contraditória do feudalismo para o capitalismo, que necessariamente procurou. Aqui não é o lugar para implementar uma regulação jurídica universal de todas as atividades sociais, como também simultaneamente transformou em questão principal da vida social a superioridade e, desse modo, a autoridade da regulação central perante todas as demais." (LUKÁCS, 2013, p. 235) Importante notar que justamente o que Lukács chama de "regulação jurídica universal" é que será chamado por Pachukanis de Direito. Igualmente importante destacar é o modo pelo 
sentido, é necessário verificar as dissonâncias e aproximações entre os dois autores também sobre este ponto, central ao que se consolidou como o cerne da crítica marxista ao Direito, a qual, em verdade, ainda está, para o bem e para o mal, sob a sombra pachukaniana. (Cf. SARTORI, 2015 c) Vejamos o delineamento da questão, pois.

Segundo Pachukanis, "foi preciso um longo processo de desenvolvimento, no qual as cidades foram o principal palco, para que as facetas da forma jurídica pudessem cristalizar-se em toda a sua precisão." (PACHUKANIS, 1989, p. 23) Ou seja, mesmo que a ênfase na gênese da forma jurídica não seja tão grande no jurista soviético, ela está presente. Nela, o autor destaca o "longo processo de desenvolvimento" pelo qual passa a forma jurídica - nota-se, novamente, portanto, que "as facetas da forma jurídica" (e não do Direito) colocam-se, segundo Pachukanis, em um passado pré-capitalista. E, neste sentido, tal qual o autor da Ontologia, o caráter processual da conformação do Direito é destacado neste momento, em que "as cidades", justamente algo desenvolvimento historicamente com forte impulso vindo do crescimento do comércio (Cf. LEFEBVRE, 1989), são um palco bastante importante deste "longo processo de desenvolvimento".

Lukács também enfocará a cidade enquanto um locus em que o "afastamento das barreiras naturais", bem como o desenvolvimento da sociabilidade humana, ganharão bastante destaque (Cf. LUKÁCS, 2013; SARTORI, 2010). E, neste sentido específico, quanto à gênese do Direito, os autores aproximam-se bastante também sob este aspecto. Se Pachukanis destaca a "cristalização" das "facetas da forma jurídica", algo que somente ocorreria em toda a sua efetividade na sociedade capitalista, o mesmo se dá com Lukács quanto ao Direito. O autor húngaro ainda destaca sobre a forma jurídica: "por mais diferenciados que sejam os conteúdos jurídicos na sua gênese e na sua vida concreta, a forma jurídica adquire homogeneidade própria somente no curso da história; quanto mais a vida social se faz social, tanto mais nítida se torna tal homogeneidade." (LUKÁCS, 1981, p. XCIV) Assim, 
pode-se mesmo traçar um paralelo entre o processo em que a "forma jurídica adquire homogeneidade própria" e o processo em que se tem a "cristalização" das "facetas da forma jurídica". O autor da Ontologia, também neste ponto, pode ser aproximado do autor da Teoria geral do Direito e o marxismo. No entanto, há de se notar que aquilo que Lukács tem em mente difere do que Pachukanis trata: se o jurista soviético trata da relação entre a forma jurídica e a mercantil, o marxista húngaro tem em mente justamente a conformação da forma jurídica enquanto algo que traz certa homogeneidade a despeito dos "mais diferenciados...conteúdos" que são abordados no Direito.

Lukács, pois, tem em mente a gênese do fetichismo que permeia a esfera do Direito. Nele, esta forma homogênea prevalece aos olhos do operador do Direito, ao passo que o conteúdo político social, não obstante ser o essencial (e o determinante) aparece eclipsado. ${ }^{22}$ A forma jurídica passaria, portanto, pela própria práxis do jurista, e o autor húngaro enfoca a questão muito mais sob este aspecto. ${ }^{23}$ Ou seja, a questão aparece de modo inverso àquele da teoria pachukaniana: pensador soviético afirma que o "momento que [...] representa a realização completa da forma jurídica: o tribunal e o processo." (PACHUKANIS, 1988 , p. 9) E, neste sentido, não deixa de tratar da questão. No entanto, enfatiza muito mais a ligação entre forma mercantil e forma jurídica ao tratar da igualdade jurídica e da figura do sujeito de direito. Assim, percebe-se que ambos tratam da práxis judicial, e também tratam da relação entre o Direito e a circulação de mercadorias. No entanto, as suas ênfases, até certo ponto, são opostas, tendo-se a relação entre a

22 Lukács parece se aproximar do significado que dá Engels à noção: "em cada caso individual os factos econômicos têm de tomar a forma de motivos jurídicos, para serem sancionados sob a forma de lei, e porque, ao fazê-lo, há também evidentemente que ter em consideração todo o sistema jurídico já em vigor, por [tudo] isto, a forma jurídica deve, então, ser tudo e o conteúdo econômico nada. Direito público e direito privado são tratados como domínios autônomos, que têm o seu desenvolvimento histórico independente, que são capazes em si mesmos de uma exposição sistemática e a requerem através de consequente extirpação de todas as suas contradições internas." (ENGELS, 1982, p. 418)

23 Novamente, vale destacar que a noção de forma jurídica difere em Lukács e Pachukanis, embora a aproximação entre as duas noções, em certo sentido, seja também evidente. Como apontamos acima, o uso lukacsiano parece aproximar-se bastante daquele de Friedrich Engels. 
esfera econômica e a jurídica traçada de modo muito mais mediado na abordagem lukacsiana que na pachukaniana. Se seguirmos Lukács, pode-se dizer que isto é essencial em uma análise cuidadosa do "ser-propriamente-assim" da sociedade capitalista.

\section{VII}

Há, no entanto, um palco comum no qual isto se dá. Trata-se da crítica ao caráter "abstrato" da forma jurídica (e, em especial, da noção de sujeito de direitos) em Pachukanis ${ }^{24}$, e da crítica ao caráter homogeneizador do Direito, que é central à crítica lukacsiana ao Direito. Os autores, pois, por caminhos diversos (que passam pela tematização da forma jurídica), convergem até certo ponto. Lukács é claro ao dizer que "o ordenamento jurídico em sentido próprio só surge quando interesses divergentes, que poderiam, em cada caso singular, insistir numa resolução violenta, são reduzidos ao mesmo denominador jurídico, são juridicamente homogeneizados." (LUKÁCS, 2013, p. 244-245) Deste modo, tal qual em Pachukanis, há em Lukács uma crítica ao modo pelo qual os interesses distintos (de indivíduos singulares e de classes sociais antagônicas) são "reduzidos ao mesmo denominador" o qual é justamente a medida por meio da qual será colocada a noção de igualdade na sociedade capitalista (relacionada por Pachukanis à questão do sujeito de direito). Contra tal formalismo das noções jurídicas, e da noção de igualdade em especial - a qual só aparece no "ordenamento jurídico em sentido próprio" - o autor húngaro postula que, mesmo nos momentos mais revolucionários da práxis burguesa, os limites dos ideais burgueses são claros: "também as práticas da Revolução Francesa raramente excederam o conceito jurídico-formal de liberdade e da igualdade" (LUKÁCS, 2007, p. 29), de tal forma que

24 Aponta o autor que "se a análise da forma mercantil revela o sentido histórico concreto da categoria do sujeito e põe a nu os fundamentos dos esquemas abstratos da ideologia jurídica, o processo de evolução histórica da economia mercantil-monetária e mercantilcapitalista acompanha a realização destes esquemas sob a forma da superestrutura jurídica concreta. Desde que as relações humanas têm como base as relações entre sujeitos, surgem as condições para o desenvolvimento de uma superestrutura jurídica, com suas leis formais, seus tribunais, seus processos, seu advogados etc." (PACHUKANIS,1988, p. 10) 
liberdade e igualdade aparecem na posição burguesa como algo incapaz de buscar a transformação real e efetiva da tessitura social, sendo necessária uma postura oposta, impossível de emergir ao se apegar ao "terreno do Direito": para o autor da Ontologia do ser social, "a realização da liberdade e da igualdade exige, portanto, a necessária transformação das condições sociais das relações humanas." (LUKÁCS, 2007, p. 28) Sem isso, seria impossível a busca de qualquer mudança efetiva na vida dos homens. ${ }^{25} \mathrm{O}$ Direito, pois, passa longe de possuir um papel transformador, diga-se de passagem, convergindo Lukács e Pachukanis também sobre este ponto específico e, em verdade, decisivo à crítica ao Direito.

Os termos jurídicos, se seguirmos o exposto, seriam essencialmente manipulatórios. Neste sentido, novamente, o autor húngaro - criticando a forma jurídica - destaca a heterogeneidade do "sentido jurídico" da igualdade e da liberdade frente a outros sentidos: "liberdade no sentido jurídico é algo de substancialmente diferente do que no sentido político, moral, ético etc." (LUKÁCS, 2013, p. 46) 26 $^{26}$ Também aponta o autor que o caráter homogeneizador do espelhamento jurídico (Cf. SARTORI, 2010) perpassa uma manipulação conceitual gigantesca no campo daquilo que é chamado de "ciência do Direito" (esta última, também, bastante criticada por Pachukanis). Nela, segundo Lukács, "os meios e as mediações mais variados da vida social devem ser organizados de tal modo que possam elaborar em si essa completude, que também no âmbito do Direito leva a uma homogeneização formal." (LUKÁCS, 2012, p. 388) No que, novamente, tem-se uma crítica decidida à forma jurídica, mesmo que esta seja distinta da crítica pachukaniana.

25 Lukácsapontasobre oslegisladores revolucionários daRevoluçãoFrancesa:"oslegisladores revolucionários da grande virada no fim do século XVIII agiram, pois, contradizendo seus ideais teóricos gerais, mas em consonância com o ser social do capitalismo, de modo ontologicamente coerente, quando em suas constituições subordinaram o representante idealista da generidade, o citoyen, ao bourgeois, que representava o materialismo dessa sociedade. Essa avaliação da importância do ser também dominou mais tarde todo o desenvolvimento capitalista. Quanto mais energicamente se desenvolvia a produção, tanto mais o citoyen e seu idealismo se tornavam componentes dirigidos pelo domínio material-universal do capital." (LUKÁCS, 2010, p. 283)

26 Novamente, vale lembrar a importância que tem para o autor a diferença específica e a autonomização existentes entre o Direito, a ética e a moral. (Cf. SARTORI, 2015 a) 
Ao se abordar o "terreno jurídico", pois, não se trataria tanto de uma esfera que parta da compreensão real e efetiva da tessitura da realidade social; antes, o âmbito jurídico, por mais que procure uma apreensão adequada da última - diz Lukács -, traz consigo um caráter sistemático e manipulador, cujos termos são inaceitáveis àqueles que procuram "a necessária transformação das condições sociais das relações humanas." (Cf. SARTORI, 2010) Diz o autor húngaro de modo claro: "com efeito, o sistema não brota do espelhamento da realidade, mas só pode ser sua manipulação homogeneizante de cunho conceitual-abstrato." (LUKÁCS, 2013, p. 239) Ou seja, os termos jurídicos não poderiam ser aceitos de modo algum. Daí, ser necessária a crítica às próprias categorias jurídicas, as quais, tratam da realidade efetiva de modo deturpado, "conceitual-abstrato". ${ }^{27}$ Elas expressam algo decorrente de uma "manipulação homogeneizante", e não o "ser-precisamente-assim” do ser social. (Cf. LUKÁCS, 2013; SARTORI, 2010) Isso seria claro ao se tratar da igualdade e da liberdade jurídicas, as quais operam em meio à realidade social justamente por meio de seu caráter "homogeneizante" e "abstrato", sendo que, em verdade, deve-se justamente se "afirmar, teórica e praticamente, a prioridade do conteúdo político-social em relação à forma jurídica." A reflexão acerca destas categorias é feita em Lukács ao se criticar o Direito como um todo e ao afirmar que, em verdade, elas não são o ponto de partida. Pachukanis, por outro lado, pretende fazer uma crítica, por assim dizer, "interna" às categorias jurídicas, mostrando que elas não se sustentam. Assim, novamente, há abordagens que são, ao mesmo tempo, convergentes e divergentes.

Para Lukács, as categorias jurídicas, portanto, são um fruto manipulatório, que "não brota do espelhamento da realidade", certamente. No entanto, isto não implica em estas categorias deixarem de operar - não obstante sua falsidade epistemológica - concretamente na realidade social; como aponta Ester Vaisman, com base em Lukács, "sua 'falsidade gnosiológica' opera eficazmente em relação a dadas

27 Neste sentido, noções importantes à teoria do Direito, como aquela de "sujeito de direito" (categoria esta que vem sendo a pedra de toque de grande parte da crítica marxista ao Direito), também precisam passar por uma crítica decidida. Voltaremos à questão mais à frente. 
necessidades decorrentes dos conflitos sociais." (VAISMAN, 2010, p. 53) A questão não é simples, pois implica na compreensão de que justamente a falsidade epistemológica, muitas vezes, é aquilo que é necessário para que, ontologicamente, as categorias jurídicas possam ser efetivas. ${ }^{28}$

\section{VIII}

Isto se dá, inclusive, ao passo que o caráter "abstrato" e "homogeneizador" do espelhamento jurídico só se conformar como tal ao passo que se toma abstrações e formas de homogeneização, por assim dizer, "bastante reais" como parâmetro: aquelas da esfera de circulação de mercadorias, enfatizada tanto por Pachukanis quanto por Lukács. A questão certamente passa pela esfera de circulação de mercadorias, no entanto, remete certamente para o próprio âmbito da produção, chegando-se às raízes do fenômeno de modo mais claro. Ela relaciona-se também com a temática da forma jurídica, relacionada à noção de igualdade e à noção de sujeito de direito, temáticas as quais vêm sendo central à crítica marxista ao Direito. Deste modo, é preciso passar por ela com algum cuidado, inclusive, com uma primeira advertência: por mais que esta crítica ao formalismo do Direito tenha consigo a busca por uma sociedade distinta (socialista, em verdade), ela, se formos seguir Lukács e Pachukanis (e, acreditamos, Mar ${ }^{29}$ ), não tem consigo uma nova noção de justiça. ${ }^{30} \mathrm{E}$ isto precisa ser destaca-

28 Como aponta José Chasin sobre a questão da "falsidade" de algumas ideologias: "enquanto falsidades é que existem e objetivam uma dada ideologia. Que compete à investigação agregar, à obviedade da falsidade daqueles, o que são em sua falsidade." (CHASIN, 1999, p. 27)

29 Dentre outros pontos, Marx critica de modo decidido a 'fraseologia da "distribuição justa"” (MARX, 2012, p. 28)

30 Vale a pena destacar isso pois, em parte, a tábua de salvação daqueles que pretendem elaborar "teorias críticas do Direito", ou mesmo teorias que busquem uma crítica ao Direito vem sendo a noção de justiça. Veja-se dois exemplos: Roberto Lyra filho, que busca uma forma de Direito que tenha uma base crítica, aponta que "volta sempre a questão da fonte suprema de qualquer Direito, inclusive do direito de produzir normas legais. A idolatria da ordem nunca elimina (apenas tenta disfarçar) o problema da Justiça." (LYRA FILHO, 1982, p. 52) Já Alysson Mascaro, que busca uma crítica ao Direito, a partir do próprio 
do já que, mesmo um autor bastante respeitado pelos dois marxistas que aqui tratamos, Lenin, disse que "o 'direito igual' equivale a uma violação da igualdade e da justiça." (LENIN, 2010, p. 112) Ou seja, a questão se coloca mesmo que o autor de Estado e revolução tenha se posicionado, de certo modo, com uma valorização da noção de justiça. Mesmo os grandes representantes do marxismo, pois, teriam se equivocado quanto ao tema. Vejamos:

Na sua crítica a Proudhon, Marx indica que o conceito abstrato de justiça de nenhum modo é um critério absoluto e eterno, a partir do qual se possa edificar uma relação de troca ideal, isto é, justa. Isto seria o mesmo que uma tentativa "para transformar as trocas químicas" em função "de ideias eternas", de "qualidades particulares" e de "afinidades", quando o que se deveria era "estudar as suas leis reais". Eis que o próprio conceito de justiça deriva da relação de troca e fora dela não tem sentido. No fundo, o conceito de justiça não contém, essencialmente, nada de novo com relação ao conceito de igualdade de todos os homens anteriormente analisado. Eis a razão por que é ridículo ver contido na ideia de justiça qualquer critério autônomo e absoluto. (PACHUKANIS, 1988, p. 112-113)

Lenin é certeiro ao criticar o "direito igual" e, neste sentido, tal qual Lukács e Pachukanis, segue de perto Marx, abordando algo central a qualquer crítica marxista ao Direito, a crítica à igualdade jurídica. Isto se dá porque a própria noção de "direito igual", e mesmo de Direito, é inseparável, mesmo que de modo mediado, da esfera da circulação mercantil; e, é preciso destacar: segundo Pachukanis, o mesmo se dá com a noção de justiça. O modo pelo qual Proudhon teria tratado da questão seria sintomático, tendo-se como base a "troca justa"; com isto, restaria claro que "o próprio conceito de justiça deriva da relação de troca e fora dela não tem sentido".

Pachukanis, diz que "o filósofo do direito pleno é aquele que, de posse do conhecimento filosófico, amplia os horizontes de seu tempo. Virulento contra as injustiças, aponta para o justo que ainda não existe." (MASCARO, 2012, p. 17) Como veremos à frente, independente do acerto ou do erro destas posições, elas não confluem com aquelas dos autores que aqui tratamos. 
Mesmo que o autor de Teoria geral do Direito e marxismo se refira anteriormente ao "conceito abstrato de justiça", aparentando, portanto, dar ensejo à busca de um conceito alternativo de justiça, não é isto que ocorre, definitivamente. A questão fica clara já que, seguindo Pachukanis, seria impossível dissociar a própria noção de justiça do conceito de igualdade jurídica, inseparável da "forma jurídica". Assim, ao seguir o autor, nota-se: contrapor a justiça ao Direito só poderia ser ilusório. Fazê-lo não traria, em verdade, "nada de novo" de modo que Pachukanis não é só um crítico do Direito, é um crítico da noção de justiça. Ela, em verdade, juntamente com a noção jurídica de igualdade, trataria de deixar intocado justamente o essencial, a conformação real e efetiva das relações de produção. E mais: a noção de justiça, como inseparável daquela de Direito, justamente possui uma base real e efetiva que torna tanto o Direito como a noção de justiça cegos diante da produção. Em Marx, em consonância, seria impossível hipostasiar a esfera de trocas:

A troca individual corresponde, também, a um modo de produção determinado, que, ele mesmo, responde ao antagonismo das classes. Mas as consciências honestas recusam-se a tal evidência. Quando se é burguês não se pode agir de outra forma a não ser ver nesta relação de antagonismo uma relação de harmonia e de justiça eterna, que não permite a ninguém fazer-se valer às expensas de outrem. Para o burguês, a troca individual pode subsistir sem o antagonismo das classes: para ele são duas coisas completamente disparatadas. A troca individual, como o burguês a figura, está longe de assemelhar-se com a troca individual tal como ele a pratica. (MARX, 2004, p. 75)

Tratar da esfera das trocas, e da "troca individual", que, com a noção de justiça, para ser vista com ares idílicos, é isolada arbitrariamente do conjunto da totalidade social, seria impossível. Seria necessário tratar de modo detido da esfera produtiva. A troca mesma "corresponde" a um "modo de produção determinado" a uma conformação objetiva do "antagonismo de classes". Aqueles que presam pela "justiça" e pela "harmonia" (as "consciências honestas"), pois, estariam deixando de considerar somente o essencial: a conformação objetiva da sociedade, 
marcada pelo inconciliável antagonismo classista. Juntamente com a noção de igualdade jurídica, pois, a "justiça eterna" nada mais traria que o "reconhecimento oficial" 31 de relações sociais estruturalmente desiguais, pois correspondentes à relações produtivas calcadas na exploração da força de trabalho e no universalismo da esfera mercantil a ela correlata. ${ }^{32}$ A questão, inclusive, aparece de modo igualmente claro em Lukács, que, ao tratar da questão da justiça, diz o seguinte:

Nesse ponto, só podemos apontar para o fato de que o sonho
de justiça inerente a todas essas exigências, enquanto ele pre-
cisar ser e foi concebido nos termos do direito, não poderá levar
além de uma concepção - em última análise, econômica - de
igualdade, da igualdade que é determinada de modo socialmente
necessário a partir do tempo de trabalho socialmente necessário

31 Para Marx, "o Direito nada mais é que o reconhecimento do oficial do fato". (MARX, 2004, p. 84) Importante notar também o apontamento de Marx sobre a relação entre justiça, "formas jurídicas" e a conformação do modo de produçaõ capitalista:"a justiça das transações que se efetuam entre os agentes da produção baseia-se na circunstância de se originarem das relações de produção como consequência natural. As formas jurídicas em que essas transações econômicas aparecem como atos de vontade dos participantes, como expressões de sua vontade comum e como contratos cuja execução pode ser imposta à parte individual por meio do Estado não podem, como simples formas, determinar esse conteúdo. Elas apenas o expressam. Esse conteúdo será justo contanto que corresponda ao modo de produção, que the seja adequado. E injusto, assim que o contradisser. A escravatura, na base do modo de produção capitalista, é injusta; da mesma maneira a fraude na qualidade da mercadoria" (MARX, 1986, p. 256)

32 Sobre o tema, aponta Lukács: "o fato de o sistema vigente do direito positivo e a factualidade socioeconômica na vida cotidiana subsistirem lado a lado e se encontrarem ao mesmo tempo emaranhados leva necessariamente aos mais diversos tipos de más interpretações da relação entre ambos. Polemizando contra tal teoria errada de Proudhon e em conformidade com a constatação da prioridade ontológica e da legalidade própria dos processos econômicos, Marx propôs a seguinte definição: "o direito é apenas o reconhecimento oficial do fato" recém-constatada do econômico. Essa definição quase aforística é extremamente rica em conteúdo, contendo já os princípios mais gerais daquela discrepância necessária entre direito e realidade econômico-social, da qual já falamos no capítulo sobre Marx. A determinação 'o fato e seu reconhecimento' expressa com exatidão a condição de prioridade ontológica do econômico: o direito constitui uma forma específica do espelhamento, da reprodução consciente daquilo que sucede de facto na vida econômica. A expressão 'reconhecimento' apenas diferencia ainda mais a peculiaridade específica dessa reprodução, ao trazer para o primeiro plano seu caráter não puramente teórico, não puramente contemplativo, mas precipuamente prático."(LUKÁCS, 2013, p. 237-238) 
e que se concretiza no intercâmbio de mercadorias, tempo de trabalho socialmente necessário que deve permanecer como base real e, por essa razão, insuperável no pensamento, de todas as concepções jurídicas de igualdade e justiça. A justiça que emerge daí consta, por sua vez, no rol dos conceitos mais ambíguos no desenvolvimento humano. Ela assume a tarefa, para ela insolúvel, de harmonizar idealmente ou até institucionalmente a diversidade e peculiaridade individual dos homens com o julgamento dos seus atos com base na igualdade produzida pela dialética do próprio processo da vida social." (LUKÁCS, 2013, p. 243)

O "sonho da justiça", como todo o sonho, estaria completamente dependente daquilo que procura abstratamente negar. Não se teria a possibilidade de valorizar unilateralmente um termo em detrimento do outro pois isto consistiria justamente em separar o "lado bom" do "lado mal" de objetividades ontologicamente unitárias, como teria feito Proudhon (Cf. MARX, 2204). Tal sonho, ao contrário do que aponta Bloch (1988), diz o marxista húngaro, "precisa ser e foi concebido nos termos do Direito" de tal modo que, também para Lukács, contrapor Direito e justiça só pode ser algo vão e fútil. As "exigências" que menciona o marxista húngaro estariam ligadas a questionamentos incapazes de ir às raízes reais e efetivas das vicissitudes da sociedade capitalista, tendo-se, assim, a total incapacidade de compreender a determinação social do Direito e da justiça. A questão, porém, é bastante nuançada. A concepção de justiça, ao mesmo tempo em que não escapa da esfera jurídica (e da produção social subsumida ao capital), não deixaria de trazer consigo grandes ambiguidades. Estas têm consigo uma função (impossível de ser realizada, segundo o autor da Ontologia do ser social) de "harmonizar" aquilo que, objetiva e essencialmente, é inconciliável. Trata-se de uma noção que, ao se contrapor abstratamente às "injustiças existentes", "coloca entre parênteses" a particularidade dos interesses sociais dos indivíduos de classes sociais antagônicas, trazendo uma descrição estilizada de uma realidade supostamente possível, e não uma crítica ontológica à mesma.

É ainda interessante notar que a função ideológica deste sonho de justiça é efetiva, segundo o autor húngaro, na medida em que só se 
pode buscar, "nos termos do Direito", "harmonizar idealmente", e não real e efetivamente, as relações sociais. Assim, o recurso à "justiça", por mais bem-intencionado que possa ser, é somente a outra face da confissão de impotência do Direito positivo. ${ }^{33}$

A questão é de grande relevo para o que tratamos já que o termo mediador entre o Direito e a justiça, também em Lukács, é a noção de igualdade (central para a crítica pachukaniana). E, também neste sentido, há confluências entre os dois autores, apesar de suas disparidades. O autor húngaro enfoca justamente a natureza, "em última análise, econômica", da noção de igualdade que aí se apresenta. Ao abordar o tema, vai às raízes sociais da questão ao enfocar a questão do "tempo de trabalho socialmente necessário" que "se concretiza no intercâmbio de mercadorias" e, neste sentido, enfoca com cuidado a base real da esfera de trocas, do Direito e da justiça. Ou seja, o marxista húngaro enxerga a produção e a circulação em uma unidade na diversidade e, explicitamente, nunca deixa de ter em conta a relação do Direito, e da igualdade que aí aparece, com a produção social das mercadorias. Deixa bastante claro se tratar do "tempo de trabalho socialmente necessário que deve permanecer como base real e, por

33 Em Lukács, a questão, também, liga à noção de "Direito natural": "ao lado do direito real, efetivamente funcionando, ao lado do assim chamado direito positivo, sempre esteve presente na consciência social dos homens a ideia de um direito não posto, que não brota de atos sociais, considerado como ideal para o primeiro, a saber, o direito natural. Esse dever possui uma importância social extremamente diferenciada em diversos períodos: de uma grande influência conservadora (direito natural católico na Idade Média), de uma força explosiva revolucionária (Revolução Francesa), a tensão se reduz muitas vezes a desejos piedosos retórico-professorais perante o direito vigente." (LUKÁCS, 2013, p. 232) A questão não será aprofundada aqui, no entanto, vale apontar que, também Pachukanis, não traça uma muralha chinesa entre o Direito positivo e o "Direito natural", no qual, inclusive, acredita encontrar aquilo de essencial à forma jurídica: "a escola do direito natural não foi apenas a expressão mais marcante da ideologia burguesa em uma época na qual a burguesia surgiu como classe revolucionária e formulou suas reivindicações de maneira aberta e consequente, mas também forneceu o mais profundo e o mais claro modelo de compreensão da forma jurídica. Não é por acaso que o apogeu da doutrina do direito natural coincidiu aproximadamente com o aparecimento dos grandes clássicos, os autores da economia política burguesa. As duas escolas se propuseram a tarefa de formular, sob a forma mais geral e, por conseguinte, mais abstrata, as condições fundamentais de existência da sociedade burguesa que a eles pareceram ser as condições naturais da existência de qualquer sociedade." (PACHUKANIS, 1989, p. 35) 
essa razão, insuperável no pensamento, de todas as concepções jurídicas de igualdade e justiça".

Ou seja, com a noção de justiça, sempre, aquilo que precisa ser suprimido é tomado como base e, assim, tem-se o "reconhecimento oficial" de uma sociedade baseada no trabalho abstrato, no trabalho subsumido à relação-capital e que se coloca por meio da troca equivalente no mercado.

Para Lukács, a "igualdade produzida pela dialética do próprio processo da vida social" da sociedade capitalista tem raízes econômicas claras e aparece com toda a força ao se ter em conta a igualdade jurídica. A crítica à igualdade e à liberdade jurídicas, pois, é clara no autor da Ontologia do ser social. Por mais que o autor não enfoque a questão com a mesma ênfase que Pachukanis, a questão é central à sua crítica à forma jurídica e ao próprio Direito. ${ }^{34}$

Esta heterogeneidade entre a crítica lukacsiana e a pachkaniana se deve, sobretudo, ao modo pelo qual o autor da Teoria geral do Direito e o marxismo equaciona a questão por meio da relação necessária e direta que acredita existir entre forma jurídica, forma mercantil e a categoria do sujeito de direito. Quanto à relação entre a forma jurídica e a mercantil, vimos que a posição do autor da Ontologia é mais mediada que a pachukaniana. Ou seja, também aqui, há proximidades marcantes nos autores. Ao mesmo tempo, porém, há dissonâncias, principalmente ao passo que a posição lukacsiana relaciona de modo bastante mais meandrado o Direito e a forma mercantil. Agora, para que não sejamos unilaterais, vale, mesmo que rapidamente, tratar da questão do "sujeito de direito".

34 Não é possível confundir esta ênfase distinta com falta de cuidado em Lukács. Neste sentido, discordamos de Alysson Mascaro quando aponta que "Lukács, na Ontologia, não chega às minúcias de Pachukanis, que desenvolve com muita ênfase a identificação da especificadade do direito à forma mercantil, fixando-se, antes, na crítica ontológica ao aspecto geral e impessoal do corpo técnico de dominação que é exigido do direito pelo capitalismo". (MASCARO, 2012, p. 547) Pelo que mostramos acima, justamente tratar das "minúcias" que marcam a relação do Direito com o trabalho abstrato, a produção capitalista e a circulação mercantil é que aproxima Lukács e Pachukanis. A parte final da afirmação de Mascaro sobre Lukács também pode ser vista com mais meandros do que no autor brasileiro; no entanto, aqui não podemos tratar da questão, restando somente apontá-la. 


\section{IX}

Para que a questão fique mais clara, é preciso que se passe por um termo que ainda não foi enfocado aqui, o "sujeito de direito". Fizemos referência à questão, mas não pudemos nos aprofundar na mesma. Isto tem uma razão: no que diz respeito às questões gerais pelas quais passamos acima, este ponto é aquele em que Pachukanis e Lukács mais se distanciam.

Neste sentido, são necessárias algumas linhas sobre o tema.

Não podemos nos alongar sobre a questão, valendo notar somente que, enquanto ela é central para o autor de Teoria geral do Direito e marxismo (Cf. NAVES, 2000; KASHIURA, 2009) o mesmo não se dá na crítica do autor húngaro ao Direito. Certamente, isto seria um grande problema (e, talvez, vá ser considerado como tal pelos pachukanianos) se os aspectos que confluem na questão não tivessem sido tratados por Lukács. E, como mostramos acima, eles foram abordados, inclusive, de modo bastante cuidadoso e, sob alguns aspectos, bastante próximos da abordagem pachukaniana. A pergunta que fica é saber porque o autor da Ontologia - tendo acesso aos mesmos textos que Pachukanis (e ainda outros) - não deu a mesma ênfase ao tema. Tal qual Pachukanis, Lukács enfoca o papel que a figura do proprietário tem nos sistemas jurídicos (Cf. SARTORI, 2010), porém, não chega a ter por aspecto essencial a crítica ao sujeito de direito. Isto precisa ser tratado com bastante cuidado, o que, aqui, in totum, não é possível. No entanto, podemos traçar algumas indicações, mesmo que breves. A questão talvez possa ser respondida tendo em conta certa ambiguidade do autor soviético ao tratar da teoria do Direito (Cf. SARTORI, 2015 c): ao mesmo tempo em que a mesma é criticada de modo decidido pelo autor, ele não deixa de buscar elaborar uma "teoria marxista do Direito" em que se dá um tratamento marxista de categorias como "sujeito", "norma", "direito subjetivo", entre outras. ${ }^{35}$ Se é certo que o autor

35 Como aponta Pachukanis, "a teoria geral do direito pode ser definida como o desenvolvimento dos conceitos jurídicos fundamentais, isto é, os mais abstratos. A esta categoria pertencem, por exemplo, as definições de 'norma jurídica', de 'relação jurídica', de 'sujeito de direito' etc. Esses conceitos são utilizáveis em qualquer domínio do 
soviético parte destas categorias, é verdade que não o faz de modo acrítico, tecendo críticas decididas contra as mesmas, que são consideradas como um ponto de partida para o tratamento marxista do Direito tal como as categorias da economia política foram para Marx criticar a economia de sua época. ${ }^{36}$

As categorias utilizadas pela economia política expressavam, a partir da posição (Standpunkt) burguesa, as próprias relações sociais de produção da época capitalista e, também por isso, apareciam como um ponto de partida para a crítica imanente da base real da sociedade capitalista. $O$ modo de pesquisa marxiano sempre parte das determinações objetivas da esfera produtiva. Lukács sempre esteve ciente disso (Cf. LUKÁCS, 2012); no entanto, um ponto importante a se estudar é se Pachukanis procedeu do mesmo modo ao partir das categorias jurídicas em uma crítica imanente das mesmas. Isto se dá porque, embora, ao contrário de Casalino (2009), não acreditemos que o autor soviético possa ter considerado essencialmente a circulação simples de mercadorias (sendo, assim, marcado por uma abordagem que não compreende a relação entre o Direito e a esfera produtiva da sociedade), há de se questionar se a pesquisa do Direito pode começar pelas próprias categorias jurídicas (mesmo que se trate de criticá-las). Tratamos das ambiguidades advindas da posição pachukaniana noutro lugar (SARTORI, 2015 c), de modo que, aqui, vale mencionar somente alguns pontos que ligam o ponto de partida de Pachukanis a

direito em decorrência de sua natureza abstrata; a sua significação lógica e sistemática permanece a mesma, independentemente do conteúdo concreto ao qual sejam aplicados." (PACHUKANIS, 1989, p. 11)

36 Como aponta Pachukanis, "não se pode objetar à teoria geral do direito, como a concebemos, que esta disciplina trate unicamente de definições formais, convencionais e de construções artificiais. Ninguém duvida de que a economia política estuda uma realidade efetivamente concreta, ainda que Marx tenha chamado a atenção a fatos como o valor, o capital, o lucro, a renda etc. não podem ser descobertos 'com ajuda de microscópios e da análise química'. A teoria do direito opera com abstrações que não são menos 'artificiais': a 'relação jurídica' ou o 'sujeito de direito' não podem igualmente ser descobertos pelos métodos de investigação das ciências naturais, embora por detrás destas abstrações escondam-se forças sociais extremamente reais." (PACHUKANIS, 1989, pp. 23-4) 
algumas de suas posições as quais, com base em Lukács, podem ser questionadas sob aspectos importantes.

Se formos seguir Lukács, o sistema jurídico propriamente dito, em que as categorias jurídicas se inserem, não é propriamente uma expressão adequada do movimento do real: "com efeito, o sistema não brota do espelhamento da realidade, mas só pode ser sua manipulação homogeneizante de cunho conceitual-abstrato." (LUKÁCS, 2013, p. 239-240) Por conseguinte, também a noção de sujeito de direito é advinda de uma apreensão essencialmente manipulatória da realidade e, neste sentido, seguindo o marxista húngaro, é algo "conceitual abstrato", oriundo de uma "manipulação homogeneizante". Quanto a isso, o próprio Pachukanis poderia concordar. No entanto, há de se perceber que, se isso é verdade, o central não é tanto a crítica ao sujeito de direito, mas àquilo que subjaz a ele, a saber, à "homogeneização" mesma que ocorre na esfera produtiva através da subsunção do trabalho ao capital. Ou seja, o central à crítica ao Direito passa a ser a crítica ao trabalho abstrato, à esfera de produção capitalista. E, assim, o sujeito de direito é um elo entre a esfera econômica e a esfera jurídica; ao mesmo tempo, porém, tomá-lo como ponto de apoio central talvez, justamente por isso (pelo caráter de "elo"), possa significar ficar no meio do caminho. Isto se coloca porque, afinal de contas, trata-se de uma categoria que não expressa a realidade social senão de modo manipulatório, tendo-se algo "conceitual-abstrato". Para que sejamos mais claros: se formos seguir Lukács, a categoria "sujeito de direito" é uma construção conceitual operante justamente em meio à forma jurídica; ela é um elo importante na compreensão da peculiaridade desta forma, no entanto, tomar como missão maior da crítica ao Direito a crítica ao sujeito de direito é atribuir mais importância a esta forma do que efetiva e realmente tem.

A questão é de grande importância pois Pachukanis não tarda a relacionar o sujeito de direito à questão da reificação e do fetichismo da mercadoria, como tratados em O capital. ${ }^{37}$ Ou seja, o marxista so-

37 Como aponta o autor soviético: "se a coisa se sobrepõe economicamente ao homem, uma vez que, como mercadoria, coisifica uma relação social que não está subordinada ao homem, ele, em contrapartida, reina juridicamente sobre a coisa, porque, ele mesmo, 
viético segue um caminho bastante próximo daquele que Lukács traz na Ontologia (Cf. SARTORI, 2010). Também se aproximam os autores ao passo que destacam o caráter "universal" da mediação jurídica ou a redução ao "mesmo denominador jurídico", somente ao passo que chega com força a sociabilidade capitalista e, neste sentido, ambos os autores destacam o caráter processual da conformação objetiva da forma jurídica. No que, justamente sobre isto, há uma diferença decisiva entre o autor soviético e o húngaro. Vejamos o que diz Pachukanis:

A crescente divisão do trabalho, a melhoria das comunicações e o consecutivo desenvolvimento das trocas fazem do valor uma categoria econômica, ou seja, a encarnação das relações sociais de produção que dominam o indivíduo. Mas para isso é preciso que os diferentes atos acidentais de troca se transformem numa circulação alargada e sistemática de mercadorias. Neste estágio de desenvolvimento o valor distingue-se das avaliações ocasionais, perde o seu caráter de fenômeno psíquico individual e assume um significado econômico objetivo. Condições reais são também necessárias para que o homem deixe de ser um indivíduo zoológico, sujeito jurídico abstrato e impessoal, e passe a ser uma pessoa jurídica. Tais condições reais são, por um lado, o estreitamento dos vínculos sociais e, por outro, o crescente poder da organização social, ou seja, da organização de classe que atinge o seu apogeu no Estado burguês "bem ordenado". A capacidade de ser sujeito jurídico desprende-se, então, definitivamente, da personalidade concreta, vivente, deixa de ser uma função da sua vontade consciente, eficaz e transforma-se em pura propriedade social. A capacidade de agir é abstraída da capacidade jurídica, o sujeito jurídico recebe um duplo na pessoa de um representante e adquire ele mesmo a

na qualidade de possuidor e de proprietário, não é senão uma simples encarnação do sujeito jurídico abstrato, impessoal, um puro produto das relações sociais. Segundo Marx: "Para relacionar estas coisas umas com as outras como mercadorias, os seus guardiões devem, eles próprios, se relacionar entre si como pessoas cuja vontade reside nestas mesmas coisas, de tal modo que a vontade de um seja também a vontade do outro e que cada um se aproprie da nova mercadoria abandonando a sua, mediante um ato voluntário comum. Eles devem, portanto, reconhecer-se mutuamente como proprietários privados"” (PACHUKANIS, 1989, p. 72) 
significação de um ponto matemático, de um núcleo onde se concentra certa soma de direitos.(PACHUKANIS, 1988, p. 73)

Pachukanis remete explicitamente ao campo da produção ao tratar da divisão do trabalho, trazendo as categorias econômicas como um tipo de "encarnação das relações sociais de produção que dominam o indivíduo". ${ }^{38}$ Neste sentido, não toma os homens como portadores (Träger) de relações econômicas em todas as épocas, mas somente quando não se tem o controle consciente da produção; quando, no lugar do controle consciente das condições sociais de vida, tem-se uma esfera de circulação em que "atos acidentais de troca se transformem numa circulação alargada e sistemática de mercadorias." Tudo isto, como já dito, supõem o trabalho abstrato, ou seja, a subsunção real do trabalho ao capital colocada universalmente. Neste sentido, o autor soviético reconhece a validade da lei do valor somente nestas condições, que pressupõe um processo histórico bastante específico. Ou seja, também neste ponto, ha alguma similitude com a posição lukacsiana. No entanto, a questão muda quando se tem a continuidade do argumento pachukaniano.

Ele, corretamente, passa pelo processo social em que se tem o "estreitamento dos vínculos sociais" (algo tratado por Lukács abundantemente na Ontologia e que gira em torno do afastamento das barreiras naturais), destaca Pachukanis também, neste campo, o processo de desenvolvimento das sociedades classistas chegando-se à sociedade burguesa e ao "Estado burguês 'bem ordenado'". Neste sentido, sua abordagem, tal qual a lukacsiana, é, também, histórica. Porém, as dificuldades com a posição pachukaniana começam quando, explicitamente, coloca-se a seguinte evolução: "condições reais são também necessárias para que o homem deixe de ser um indivíduo zoológico,

38 A questão remete ao processo pelo qual as relações sociais mesmas vêm a aparecer como potências estranhadas. Tal tema é bastante recorrente em todo $O$ capital e também na obra tardia de Engels, principalmente no Anti-Düring. Em nossa opinião, ela remete diretamente à questão do estranhamento (Entfremdung), tido pela tradição althusseriana como algo superado por Marx. É interessante, mesmo que brevemente, apontar ecos da problemática também em Pachukanis. Para Lukács, ela é central. Aqui, não poderemos tratar da questão, mas, talvez, seja possível certa aproximação entre os dois autores que aqui tratamos também sobre este aspecto, que envolve a relação entre estranhamento e reificação. 
sujeito jurídico abstrato e impessoal, e passe a ser uma pessoa jurídica." Ou seja, passa-se do "sujeito jurídico abstrato e impessoal" à "pessoa jurídica" e não pelo processo em que o homem, como ser social, por meio de diversas mediações, e com base nas mudanças que ocorrem na esfera produtiva, desenvolve-se política, jurídica, filosófica, artística, religiosa, enfim, ideologicamente. ${ }^{39}$ Ou seja, por um momento, Pachukanis parece tomar aquilo que é o resultado de uma "manipulação homogeneizante de cunho conceitual-abstrato" como aquilo de central para explanar o desenvolvimento histórico e objetivo da realidade efetiva. Ou seja, seria preciso falar do processo em que, com sua autoatividade, o homem desenvolve relações de produção que, ao fim, dão ensejo ao trabalho que passa pela subsunção real ao capital - o processo que leva à autoconstituição do homem como tal tem por central a esfera produtiva, passando pelo trabalho e tendo por essencial o desenvolvimento das relações de produção que, no capitalismo, levam ao trabalho abstrato. (Cf. LUKÁCS, 2013) O autor soviético certamente não deixa de ter isto em mente. No entanto, sua expressão, no ímpeto de desenvolver um tratamento marxista do Direito, não deixa de trazer certa forma de analogia, que pode ser problemática, acerca da relação entre a crítica à teoria do Direito e a crítica à economia política. (Cf. PAÇO-CUNHA, 2014; SARTORI, 2015 c) Ao se trazer o processo de desenvolvimento dos homens enquanto algo que vai do "indivíduo zoológico, sujeito jurídico abstrato e impessoal, e passe a ser uma pessoa jurídica", talvez, o procedimento pachukaniano traga o fato de, no autor, as categorias advindas de uma "manipulação homogeneizante de cunho conceitual-abstrato" não tenham sido criticadas de modo suficiente. Se é exatamente isto que pretende o autor da Teoria geral do Direito e marxismo, ao tomá-las como categorias centrais ao desenvolvimento mesmo da sociabilidade - e não como um termo mediador, entre outros, neste processo - ele chega a certa hipertrofia da importância da dimensão jurídica.

39 Marx fala de "formas ideológicas, sob as quais os homens adquirem consciência desses conflitos", entre elas, inclusive, as "formas jurídicas, políticas, religiosas, artísticas e filosóficas". (MARX, 2009, p. 46) 
A questão aparece de tal modo em Pachukanis que, assim como na esfera econômica o homem apareceria como um feixe de relações econômicas, como um mero portador delas, no Direito, ele apareceria, na figura do sujeito de direito, em especial, com a "pessoa jurídica", como "um núcleo onde se concentra certa soma de direitos". E, neste sentido, uma das tarefas a se colocar para aqueles que pretendem dar continuidade a uma crítica marxista ao Direito é ver até que ponto ter por central a crítica à noção de sujeito de direito não seria dar mais importância que a merecida à "manipulação homogeneizante de cunho conceitual-abstrato." Trata-se de averiguar a envergadura da crítica pachukaniana à teoria do Direito para que, então, seja possível, ao ver com o devido cuidado as posições do autor, dar uma continuidade sólida à sua empreitada. Neste sentido, a tematização cuidadosa sobre a centralidade ou não da crítica à noção de sujeito de direito pode ser bastante importante, pois, aqueles que se pretendem marxistas sabem que a crítica ao Direito e à teoria do Direito só faz sentido se relacionada a uma cuidadosa crítica global ao capitalismo.

\section{X}

Com isso, pode-se apontar uma última questão que, ao mesmo tempo, une e afasta Lukács e Pachukanis. ${ }^{40}$ Trata-se da questão da transição socialista, em que ambos, decididamente, colocam-se pela extinção do Direito. O central aqui é ver como este ponto se relaciona ao que foi pontuado anteriormente, e que gira em torno da gênese e conformação da forma jurídica. Deste modo, é possível fecharmos nossa exposição traçando uma unidade existente tanto na obra de um autor como na de outro, vendo-se como que, de modo coerente com a concepção geral que têm, tais pensadores, simultaneamente, podem ser vistos em conjunto, mas têm posições distintas.

É importante pontuar que os autores trazem a impossibilidade de, de um dia para o outro, extinguir-se o Direito. Pachukanis diz que

40 Isto se dá em termos expositivos, pois ainda seria possível tratar de diversos outros aspectos sobre os pensadores. 
"supressão da forma jurídica está ligada não apenas ao quadro da sociedade burguesa, mas também a uma emancipação radical em relação a todas as suas sobrevivências." (PACHUKANIS, 1988, p. 29) Para ele, portanto, a supressão do Direito, em verdade, só poderia se dar com a supressão do próprio capitalismo, e de suas "sobrevivências", sendo, neste ponto, Pachukanis muito próximo daquilo que Marx postula na Crítica ao programa de Gotha, remetendo também ao fim do "estreito horizonte do Direito burguês" que, pontua Marx, ainda marca a transição socialista (Cf. MARX, 2012); o autor soviético, em clara referência à obra marxiana, diz que "o processo posterior da superação da forma jurídica reduzir-se-ia à passagem progressiva da distribuição de equivalentes (para uma certa soma de trabalho uma certa soma de produtos sociais) à realização da fórmula do comunismo evoluído "de cada um segundo as suas capacidades, a cada um segundo as suas necessidades'." (PACHUKANIS, 1988, p. 87) Seguindo a distinção leninista entre socialismo e comunismo (Cf. LENIN, 2010), o autor da Teoria geral do Direito e marxismo, portanto, traz a questão da extinção do Direito relacionada à própria superação das sociedades classistas e, com elas, da esfera de circulação mercantil, amparada no trabalho abstrato. ${ }^{41}$ No lugar da "distribuição

41 Sobre estas questões, duas passagens de Marx são bastante importantes e podem ser citadas aqui, somente para que não restemos silentes. Na primeira, Marx fala da transição dizendo que, "apesar desse progresso, esse igual direito continua marcado por uma limitação burguesa. O direito dos produtores é proporcional a seus fornecimentos de trabalho; a igualdade consiste, aqui, em medir de acordo com um padrão igual de medida: o trabalho. Mas um trabalhador supera o outro física ou mentalmente e fornece, portanto, mais trabalho no mesmo tempo ou pode trabalhar por mais tempo; e o trabalho, para servir de medida, ou tem de ser determinado de acordo com sua extensão ou sua intensidade, ou deixa de ser padrão de medida. Esse igual direito é direito desigual para trabalho desigual. Ele não reconhece nenhuma distinção de classe, pois cada indivíduo é apenas trabalhador tanto quanto o outro; mas reconhece tacitamente a desigualdade dos talentos individuais como privilégios naturais e, por conseguinte, a desigual capacidade dos trabalhadores. Segundo seu conteúdo, portanto, ele é, como todo direito, um direito da desigualdade. $\mathrm{O}$ direito, por sua natureza, só pode consistir na aplicação de um padrão igual de medida; mas os indivíduos desiguais (e eles não seriam indivíduos diferentes se não fossem desiguais) só podem ser medidos segundo um padrão igual de medida quando observados do mesmo ponto de vista, quando tomados apenas por um aspecto determinado, por exemplo, quando, no caso em questão, são considerados apenas como trabalhadores e neles não se vê nada além disso, todos os outros aspectos são desconsiderados." (MARX, 2012, pp. 31-32) Depois, aponta o autor: "Numa fase superior da sociedade comunista, 
de equivalentes", pois, a "fórmula do comunismo evoluído". Lukács, por seu turno, aponta algo que tem uma relação bem próxima ao falar da relação do Direito e o socialismo - este último termo sendo visto, aqui também, como entendido por Lenin:

\begin{abstract}
Nesta perspectiva, não há diferença entre o direito socialista e o direito capitalista. Mais ainda: eu não me referiria a direito socialista. Remeto aqui a Marx. Na Crítica ao Programa de Gotha, Marx afirma claramente que o direito dominante no socialismo é ainda o direito civil, mesmo que sem a propriedade privada, e que este lado formal do direito foi desenvolvido pela civilização capitalista; e não há dúvidas de que ele permanece, no socialismo, enquanto direito. É inquestionável que não existe um direito socialista; na verdade, o desenvolvimento do socialismo rumo ao comunismo criará uma condição social que não necessitará do direito; por isto, não creio que, desse ponto de vista, se possa falar num direito socialista especial. (LUKÁCS, 2008, p. 245)
\end{abstract}

Tal qual Pachukanis, em Lukács, o Direito propriamente dito não se coloca no socialismo. Partindo da Crítica ao programa de Gotha, tal qual faz o autor da Teoria geral do Direito e marxismo, tem-se em conta que, de início, ainda se está no "estreito horizonte do Direito burguês". Para Lukács, isto coloca-se na medida em que "o Direito dominante no socialismo ainda é o civil" (algo, aliás, que dialoga bastante com a posição de Pachukanis sobre a prevalência do Direito privado na conformação do Direito). Ou seja, também neste ponto, há uma convergência considerável entre os autores. A questão se torna ainda mais clara quando ambos negam que se possa falar "num Direito socialista especial", tratando-se, antes, do desenvolvimento "do socialismo rumo ao comunismo". Isto, segundo o autor da Ontologia do ser

quando tiver sido eliminada a subordinação escravizadora dos indivíduos à divisão do trabalho e, com ela, a oposição entre trabalho intelectual e manual; quando o trabalho tiver deixado de ser mero meio de vida e tiver se tornado a primeira necessidade vital; quando, juntamente com o desenvolvimento multifacetado dos indivíduos, suas[39] forças produtivas também tiverem crescido e todas as fontes da riqueza coletiva jorrarem em abundância, apenas então o estreito horizonte jurídico burguês poderá ser plenamente superado e a sociedade poderá escrever em sua bandeira: 'De cada um segundo suas capacidades, a cada um segundo suas necessidades!'”. (MARX, 2012, p. 33) 
social, "criará uma condição social que não necessitará do Direito". Lukács também destaca a permanência do "lado formal do Direito", o que, como vimos acima, em sua teoria, traz íntima relação com a questão da forma jurídica, central a Pachukanis. Ou seja, tal qual o marxista soviético, Lukács também procura a extinção da forma jurídica, o que somente seria possível com a supressão, no comunismo, das próprias sociedades classistas, bem como do trabalho abstrato e da troca de equivalentes que se soerguem sobre ela. ${ }^{42}$ Ou seja, haveria, também na transição, uma espécie de "estreito horizonte do Direito burguês", horizonte este o qual precisaria ser superado; no entanto, mesmo neste momento, não trata de um "Direito especial”: para Lukács, explicitamente, "não existe um direito socialista".

Neste sentido, também sob este aspecto, há uma convergência grande entre os autores que aqui tratamos. No entanto, como não poderia deixar de ser, não se têm só convergências. A primeira questão que separa os autores é a centralidade que teria o Direito ao se tratar da questão da transição: Pachukanis, na esteira de Engels ${ }^{43}$, acredita que nas sociedades capitalistas (principalmente as de sua época), "a ideologia jurídica se torna a ideologia por excelência e (...) também a defesa dos interesses de classe dos exploradores surge, com um sucesso sempre crescente, como a defesa dos princípios abstratos da subjetividade jurídica." (PACHUKANIS, 1989, p. 10) Ou seja, a crítica ao Direito traria consigo a crítica à ideologia "por excelência" e, neste sentido, "a defesa dos interesses de classe dos exploradores" apareceria, principalmente, por meio do Direito e da forma jurídica.

Ou seja, novamente, aquilo que apareceu na posição pachukaniana ao se tratar de uma "teoria do Direito" também aparece aqui, algo

42 Pelo que apontamos acima, resta claro que a questão foi concebida de modo bastante similar por Pachukanis. A crítica ao trabalho abstrato também é realizada no autor soviético, embora, claro, fosse possível algum aprofundamento desta crítica. Para uma tentativa de aprofundamento, próxima à "nova crítica do valor" (que parte da obra de Kurz), Cf. NASCIMENTO, 2015.

43 Engels aponta que "a bandeira religiosa tremulou pela última vez na Inglaterra no século XVII, e menos de 50 anos mais tarde aparecia na França, sem disfarces, a nova concepção de mundo (Weltanschauung), fadada a se tornar clássica para a burguesia, a concepção jurídica de mundo (jurisdiche Weltanschauung). (ENGELS; KAUTSKY, 2012, p. 18) 
que, caso se tome Lukács como referência, poderia ser chamado de uma sobrevalorização do papel do Direito por parte do autor soviético (mesmo que a questão apareça com uma crítica decidida à esfera jurídica). Com isso, talvez, tenha-se um risco de se enfocar com menos força que necessário a própria conformação objetiva das relações de produção, como fica claro pela posição pachukaniana sobre o planejamento $^{44}$, tema, diga-se de passagem, importante ao se ter em mente qualquer concepção acerca do que seria o socialismo:

O planejamento verdadeiro começa onde a atividade do estado toma o lugar do assim chamado motivo econômico, isto é, o motivo do lucro individual, o interesse egoísta do sujeito econômico isolado. Ao mesmo tempo, o planejamento estatal é caracterizado pela preponderância do aspecto técnico e organizacional do conteúdo sobre os aspectos formais. Atos legislativos e administrativos, transformados em tarefas operacionais, preservam somente um aspecto muito fraco de elementos legais, isto é, formais. (PACHUKANIS, 1980, p. 267)

O aspecto "técnico e organizacional", bastante destacado por Pachaukanis sobre a questão, seria decisivo na supressão do Direito, já que se teria no lugar do último a "regulação técnica" (PACHUKANIS, 1989 , p. 50), oposta pelo pensador justamente aos "aspectos formais", que, no autor, remetem claramente à questão da forma jurídica. No lugar do Direito (e dos "atos legislativos" e "administrativos"), ter-se-iam meras "tarefas operacionais" as quais tirariam de campo "elementos legais, isto é, formais" - a supressão do Direito, portanto, é vista como sinônimo da preponderância das "regras técnicas", aspecto este que é, no mínimo, problemático e que já foi criticado, inclusive, por Márcio Naves, maior especialista e defensor de Pachukanis no Brasil. ${ }^{45}$

44 No caso, é preciso ficar atento às ressalvas que fizemos antes quanto à existência efetiva de um tratamento pachukaniano acerca das relações de produção e do trabalho abstrato em especial. As limitações do tratamento pachukaniano também estão fortemente ligado a um contexto ideológico em que o estilo de planejamento soviético, efetivamente, parecia poder fornecer uma base verdadeira ao socialismo e mesmo para o comunismo.

45 Para nossa posição sobre a questão, Cf. SARTORI, 2015 c. Márcio Naves, grande conhecedor de Pachukanis, aponta o seguinte: "o limite da posição de Pachukanis decorre 
Tal caráter problemático da abordagem pachukaniana se apresenta porque o planejamento, conjuntamente com a valorização do aspecto "técnico organizacional", corre sério risco de não levar à diante (no sentido da autogestão dos próprios trabalhadores) a crítica às relações de produção que saem do bojo do capitalismo, neste sentido, obstacularizando a própria supressão da circulação mercantil (e das relações de produção a ela subjacente) e do Direito - ou seja, o autor da Teoria geral do Direito e marxismo talvez tenha enxergado uma superação efetiva do Direito aonde ela não poderia, de modo algum, encontrar-se. Se Pachakanis fosse ser coerente com sua própria formulação, em que a forma jurídica se liga ao trabalho abstrato na esfera de circulação mercantil, seria necessária uma crítica ao próprio assalariamento e à própria divisão do trabalho vigente nas fábricas soviéticas; e a questão, ao menos nos escritos pachukanianos, não aparece como central. ${ }^{46}$ Correlato a isso, tem-se também, por parte do autor, a aceitação do Estado enquanto um elemento importante do socialismo (Cf. SARTORI, 2015 c), de tal maneira que a questão emerge enquanto a solução para o definhamento do Direito é trazida de modo até mesmo tecnicista: "o planejamento estatal é caracterizado pela preponderância do aspecto técnico e organizacional do conteúdo sobre os aspectos formais". (Cf. LUKÁCS, 1966) Ou seja, a extinção do Direito, por vezes, parece não ser confluente com a extinção do Estado, o que contraria frontalmente a obra marxiana. (Cf. SARTORI, 2012) Ao que parece, isto seria, até certo ponto, uma consequência desagradável do grande papel atribuído por Pachukanis ao Direito: sua concepção de "regras técnicas", em verdade, pressupõe o aparato estatal e decorre, até certo ponto, da ausência de tratamento cuidadoso sobre a política, tendo-se como outra face de uma "teoria geral do

de sua concepção de que o socialismo possa conhecer normas de caráter 'técnico', não afetadas pela luta de classes, 'isoladas' do processo de transformação das relações sociais, normas rigorosamente 'neutras', do ponto de vista da classe, do ponto de vista da luta política e ideológica que as massas travam contra as formas de existência do capital." (NAVES, 2000, p. 121)

$46 \mathrm{Na}$ época do autor a questão aparecia ainda em muitos outros autores, sobretudo, em Bukharin, bastante criticado por Lukács no que toca o papel da técnica. Para uma crítica detida a este aspecto, cf. LUKÁCS, 2012, 2013, 1966. 
Direito" marxista a sobrevalorização do Direito. Ao deixar de tematizar explicitamente a necessária crítica à política, tem-se a subestimação da necessidade de uma crítica decidida ao Estado e ao tecnicismo. (Cf. SARTORI, 2015 c)

A questão ainda necessita de estudos posteriores, certamente. No entanto, é bom apontá-la aqui para que se tenha uma oposição entre a concepção pachukaniana e a lukacsiana. Destacamos, pois: o autor da Ontologia, em sua maturidade ${ }^{47}$, tem uma posição oposta sobre o tema. Na medida mesma em que não toma a crítica ao Direito como o central na transição (mesmo que trate dela), ele enfatiza a questão da autogestão, ligando-a à noção de "democracia da vida cotidiana":

Eu diria que a autogestão operária é uma das questões mais importantes para o socialismo. Para mim, é incorreto quando muita gente opõe-se ao stalinismo com uma democracia em abstrato, mais precisamente, com uma democracia burguesa. Marx descreveu a estrutura geral da democracia burguesa já nos anos de 1840; ela é construída na antítese entre o idealismo do cidadão e o materialismo do burguês, e o inevitável resultado do crescimento e desenvolvimento do capitalismo é que o burguês fica no topo e o idealismo do cidadão torna-se seu servo. Em contraste, a essência do desenvolvimento socialista - que começou com a Comuna de Paris e continuou com duas Revoluções Russas - é conhecido por um nome: conselhos de trabalhadores. Para expressar isso no plano teórico nós podemos dizer se tratar da democracia da vida cotidiana. (LUKÁCS, 1970, p. 41)

Como vimos, Lukács, decididamente, coloca-se como um crítico ao Direito. Fala claramente em sua extinção, tal qual Pachukanis. No entanto, em sua concepção de transição socialista, a relação entre sociedade civil-burguesa e Estado, entre o burguês e o cidadão, é que é central. Por mais que a questão tenha a mediação jurídica como algo de grande relevo, ela é o termo mediador entre a transformação

47 Esta ressalva é bastante importante. Isto se dá, até mesmo porque a concepção de planejamento de Lukács em História e consciência de classe, escrita na mesma época que Teoria geral do Direito e marxismo, é muito similar à pachukaniana, podendo, pois, ser criticada de modo decidido. 
a se dar na esfera política e na esfera econômica, e não o campo de batalha central. ${ }^{48}$ Ou seja, a extinção do Direito é muito mais uma consequência da supressão da relação-capital e do Estado que qualquer outra coisa. Neste sentido preciso, a crítica ao Direito é, por assim dizer, "parasitária" da crítica à economia capitalista e ao Estado. Assim, Lukács afasta-se de Pachukanis, não obstante, Pachukanis tenha também demonstrado aspectos de uma crítica ao stalinismo em sua obra (Cf. NAVES, 2000), não podendo, tal qual Lukács, ser visto simplesmente enquanto alguém que teve uma atitude acrítica frente ao "socialismo" das décadas de 20 e de 30.49

No final de sua vida, o marxista húngaro enfatizou com especial vigor a sua crítica ao stalinismo e àquilo que foi chamado de socialismo no século XX. ${ }^{50}$ (Cf. SARTORI, 2013) Em oposição a estes, destacou a centralidade da questão da democracia somente enquanto esta tivesse consigo a "autogestão operária", o que acaba o distanciando de Pachukanis. Porém, se formos olhar com cuidado, em determinado sentido, nem tanto assim: é interessante destacar que o texto a que tanto Lukács quanto o autor de Teoria geral do Direito e marxismo fazem referência em suas obras ao tratar da questão da cidadania é o mesmo: Sobre a questão judaica, obra bastante valorizada pelos dois pensadores (na contramão da vertente althusseriana do marxismo, diga-se de passagem). A retomada lukacsiana dos "conselhos de tra-

48 Como aforma Lukács sobre as constituições que já na Revolução Francesa: "estas Constituições partem da oposição-unidade entre homme (bourgeois) e citoyen. Citoyen quer dizer aqui, obviamente, o cidadão tornado "idealista", destacado de todos os vínculos materiais da existência socioeconômica; o homme, ao contrário, é aquele que faz parte da sociedade civil[-burguesa]. E Marx não esquece de observar que, neste liame indissolúvel (na medida em que todo citoyen é também homme), as Constituições revolucionárias rebaixam o cidadão à condição de servidor dos chamados direitos humanos. Com isso, elas admitem a real supremacia social do homem material, econômico, privado, sobre o cidadão ideal." (LUKÁCS, 2008, p. 89-90) Na passagem, Lukács, inclusive, critica o aspecto mais "progressista" do Direito, os "direitos humanos"; o central nela, porém, está em conceber o Direito, e a constituição em especial, como um termo mediador entre o "bourgeois" e o "citoyen", tratando-se, no socialismo, justamente se superar ambos.

49 Cf. NAVES, 2000; TERTULIAN, 2007.

50 Claro, neste ponto, é bastante importante lembrar que Pachukanis foi morto pelo stalinismo em 1937 e, também por isso, não pôde chegar às conclusões a que chega Lukács no final de sua vida (o autor morreu em 1971). 
balhadores", explicitamente, coloca-se como uma forma de mediação entre a sociedade civil-burguesa e o Estado, de tal feita que, pode-se, até certo ponto dizer: se Pachukanis apoia-se em "regras técnicas", pressupondo o Estado e não o problematizando de modo suficiente, o marxista húngaro traz como mediação entre o econômico e o político na transição, não "regras técnicas", mas a própria autogestão da produção. Somente assim seria possível superar a oposição entre o cidadão e o burguês, que marca a ideologia e a democracia burguesas. Contra uma "noção abstrata de democracia" (na verdade, inseparável da democracia burguesa, segundo Lukács), o autor traz a noção de democracia socialista e de "democracia da vida cotidiana" somente ao passo que se trata de modificar substancialmente a produção material. ${ }^{51}$ Aí encontra-se a consequência concreta da "sobrevalorização" pachukaniana do Direito.

Ao contrário de Pachukanis, e até mesmo devido à época distinta em que escreveu suas obras maduras, Lukács trata de relacionar a necessidade de transformar efetivamente a base e a produção materiais para, com isso, chegar-se à possibilidade de transformação do todo social. Não é algo acidental, portanto, não se ter no autor da Ontologia, uma análise focada somente no Direito. Nas obras que mencionamos, ele aborda o tema em meio a tantos outros. Tal qual em Marx, acreditamos, isto se dá porque a crítica ao Direito, ao final, é também a crítica ao próprio capitalismo e a suas determinações histórico-sociais, sendo que esta última crítica possui muitos meandros, que passam pelo Direito, mas não o tem por central. Ou seja, a crítica ao Direito, em certo sentido, está subordinada à crítica à conformação objetiva das relações de produção capitalistas, sendo que a política, por exemplo, encontra-se ligada muito mais pungentemente que o Direito a estas relações. O último, certamente, é essencial na própria forma pela qual se dá a venda e compra da força de trabalho (como destacou, sobretudo, Pachukanis) e isto, de modo algum, pode ser negligenciado.

51 Como aponta Lukács: "a tarefa da democracia socialista é penetrar realmente na inteira vida material de todos os homens, desde a cotidianidade até as questões mais decisivas da sociedade; é dar expressão à sua sociabilidade enquanto produto da atividade pessoal de todos os homens." (LUKÁCS, 2008, p. 117) 
Porém, se seguirmos Lukács, podemos dizer que, tal qual é impossível se falar de um "Direito socialista", também não se pode falar de uma "teoria marxista do Direito", como, com vários meandros, sugere Pachukanis. (Cf. SARTORI, 2015 c) Esta ênfase do marxista soviético, relacionada às condições históricas da elaboração de sua teoria (Cf. NAVES, 2000), fizeram com que sua concepção de transição tivesse por central as "regras técnicas" as quais, neste sentido preciso que aqui tratamos, não figuram como algo simplesmente acidental na teoria pachukaniana, integrando-se organicamente em sua monumental teoria do Direito. (Cf. SARTORI, 2015 c)

\section{$\mathbf{X I}$}

Aqui, não pretendemos esgotar a abordagem que procura a possibilidade de ler Pachukanis juntamente com Lukács. Passamos muito longe disso, aliás: nosso trabalho somente dá o primeiro passo em direção a um diálogo entre pachukanianos e lukacsianos (e entre aqueles que têm por referência estes autores, e outros, como Althusser). Tal diálogo, pretendemos demonstrar, pode ser bastante proveitoso já que há várias aproximações entre estes autores aqui abordados quanto à gênese do Direito, à relação deste com o capitalismo, com a forma jurídica e com as questões que permeiam o fetichismo da mercadoria. Também no que toca a transição, pensar ambos autores em conjunto pode ser bastante interessante, tendo-se questões bastante importantes (para aqueles engajados no projeto de transformação concreta da sociedade) sendo trazidas à tona de modo decisivo. Só isto já justificaria um estudo detido da posição de ambos autores já que, em parte, uma tarefa essencial para o marxismo do século $X X I$ é repensar as experiências do século $X X$ à luz das aporias trazidas pelo modo pelo qual tentou-se trazer a transição socialista à tona.

Concluímos, portanto, que há toda uma agenda de pesquisa a ser trazida quando se tem em conta a obra dos autores que aqui tratamos. A obra de Lukács certamente não tem a questão do Direito por central; no entanto, pelo que trouxemos aqui, resta que ela é capaz, inclusive, de propiciar um diálogo e um embate com as posições de Pachukanis. 
Questões centrais nesta empreitada são aquelas que dizem respeito à especificidade do Direito, à forma jurídica, à relação entre Direito e capitalismo e à transição socialista. Ou seja, tem-se temas bastante relevantes ao se tratar do desenvolvimento de uma posição decididamente crítica acerca da sociedade presente. A partir disso, pode-se mesmo tratar de buscar desenvolver com todo o fôlego uma crítica ao Direito, crítica esta a qual, se quer ser frutífera, segundo Lukács, só pode ser uma crítica ontológica, uma crítica à própria conformação objetiva do Direito e daquilo a ele subjacente. Se Pachukanis apontou que "a crítica marxista da teoria geral do Direito ainda está em seu início" (PACHUKANIS, 1989, p. 1), é mais que necessário um empenho sério neste sentido ainda hoje e o que pretendemos trazer aqui são alguns pontos a serem pensados com cuidado nesta tarefa.

\section{BIBLIOGRAFIA:}

ALMEIDA, Silvio Luis. Crítica da subjetividade jurídica em Lukács, Sartre e Althusser. In: In: Direito e práxis. Rio de Janeiro: UFRJ, 2016 (no prelo)

. O Direito no jovem Lukács. São Paulo: Alpha-Ômega, 2006.

ALTHUSSER, Louis. A favor de Marx. Tradução por Dirceu Lindoso. São Paulo: Zahar, 1979.

BETTELHEIM, Charles. A luta de classes na URSS (1917-1923). Tradução por Bolívar Costa. Rio de Janeiro: Paz e terra, 1979.

BETTELHEIN, Chales; SWEEZY, Paul. A transição para o socialismo. Lisboa: Edições 70, 1978

BLOCH, Ernst. Natural Law and Human Dignity. Tradução por Dennis J. Schmidt. Cambridge Mass: MIT Press, 1988.

CASALINO, Vinícius. O Direito e a mercadoria: para uma crítica marxista da teoria de Pachukanis. São Paulo: Dobra Universitária, 2011. 
CHASIN, José. O Integralismo de Plínio Salgado: Forma Regressiva no Capitalismo Hiper-tardio. Belo Horizonte: Uma Editorial, 1999.

CLAUDIN, Fernando. A crise o movimento comunista. Tradução por José Paulo Netto. São Paulo: Expressão popular, 2013.

ENGELS, Friedrich. Ludwig Feuerbach e o fim da filosofia clássica alemã. Tradução por José Barata-Moura. In: Obras escolhidas. Moscovo, 1982, p. 418) (disponível em <www.marxists.org>)

ENGELS, Friedrich; KAUTSKY, Karl. O socialismo jurídico. Trad. Márcio Naves e Lívia Cotrim. São Paulo: Boitempo, 2012.

KASHIURA JR., Celso Naoto. Crítica da igualdade jurídica. São Paulo: Quartier Latin, 2009. Sujeito de direito e capitalismo. São Paulo: Expressão Popular, 2014

LEFEBVRE, Georges. 1789, o surgimento da Revolução Francesa. Rio de Janeiro: Paz e Terra, 1989.

LENIN, V.I. Estado e revolução. Tradução por Aristides Lobo. São Paulo: Expressão popular, 2010.

LYRA FILHO, Roberto. O que é Direito? São Paulo: Brasiliense, 1982. LÖWY, Michael. A evolução política de Lukács. São Paulo: Cortez, 1998. LUKÁCS, György. Conversando com Lukács. Traduzido por Giseh Vianna Konder. Rio de Janeiro: Paz e Terra, 1969.

Estética, La Peculiaridad de lo Estético. Tradução por Manuel Sacristan. V. III - Questiones Preliminares y de Princípio. México: Ediciones Grijalbo, 1966.

. La Riproduzione, Ontologia Dell' Essere Sociale II. Riuniti. Roma. 1981 - Disponível em: <http://www.sergiolessa.com>. Acesso em: 24 fev. 2008. Trad. Sergio Lessa.

. O jovem Marx e outros escritos filosóficos. Tradução por Carlos Nelson Coutinho e José Paulo Netto. Rio de Janeiro: UFRJ, 2007. 
Ontologia do ser social I. Tradução por Nélio Schneider. São Paulo: Boitempo, 2012.

. Ontologia do ser social II. Tradução por Nélio Schneider. São Paulo: Boitempo, 2013,

. Prolegômenos para uma Ontologia do Ser Social. Tradução por Lya Luft e Rodnei Nascimento. São Paulo: Boitempo, 2010. Socialismo e democratização. Tradução por José Paulo Netto e Carlos Nelson Coutinho. Rio de Janeiro: UFRJ, 2008 The Twin Crisis. In: New Left Review I/60. London, 1970 . Technology and Social Relations. In: New Left Review I/39. London, 1966

MACHADO, Carlos Eduardo Jordão. As formas e a vida: estética e petica no jovem Lukács (1910-1919). São Paulo: Unesp, 2003.

MARX, Karl. Contribuição à Crítica da Economia Política. Tradução Florestan Fernandes. São Paulo: Expressão Popular, 2009.

. Crítica ao programa de Gotha. Tradução por Rubens Enderle. São Paulo: Boitempo, 2012

. Miséria da filosofia. Tradução por J. C Morel. São Paulo: Icone, 2004

. O Capital, Volume I. Tradução por Regis Barbosa e Flávio R. Kothe São Paulo: Nova Cultural, 1988.

. O Capital, Volume IV. Tradução por Regis Barbosa e Flávio R. Kothe São Paulo: Nova Cultural, 1986,

MARX, Karl; ENGELS, Friedrich. Cultura, arte e literatura: textos escolhidos. Tradução por José Paulo Netto. São Paulo: Expressão popular, 2010.

. Ideologia alemã. Tradução por Rubens Enderle. São Paulo: Boitempo, 2007. 
MASCARO, Alysson Leandro Barbate. Filosofia do direito. São Paulo: Atlas, 2012.

Latin, 2009.

Lições de sociologia do Direito. São Paulo: Quartin

MÉSZÁROS, István. Para além do capital: rumo a uma teoria da transição. Tradução por Paulo Cezar Castanheda e Sérgio Lessa. São Paulo: Boitempo, 2002.

NASCIMENTO, Joelton. Com Pachukanis, para além de Pachukanis: direito, dialética da formavalor e crítica do trabalho. In: Verinotio: Revista On Line de Filosofia e Ciências Humanas, $n^{\circ}$ 19. Belo Horizonte: 2015 (disponível em <www.verinotio.org>)

- O Direito no jovem Lukács (resenha). In: Verinotio: Revista On Line de Educação e Ciências Humanas, $n^{\circ} 11$. Belo Horizonte: 2007 b (disponível em <www.verinotio.org>)

NAVES, Márcio Bilharinho. Marxismo e Direito: um estudo sobre Pachukanis. Boitempo: São Paulo, 2000.

Popular, 2014.

A questão do direito em Marx. São Paulo: Expressão

NAVES, Márcio Bilharinho; KASHIURA JR., Celso Naoto. Pachukanis e a Teoria geral do direito e marxismo. Direito e realidade. Monte Carmelo: Núcleo de Estudos Pachukanianos, 2011.

PACHUKANIS, E.P. Selected writings on Marxism and law. Trad. Peter B. Maggs. Londres: Academic Press, 1980.

.Teoria geral do Direito e marxismo. Tradução por Silvio Donizete Chagas. São Paulo: Acadêmica, 1988.

. Teoria geral do direito e o marxismo. Tradução por Paulo Bessa. Rio de Janeiro: Renovar, 1988.

PAÇO CUNHA, E. Considerações sobre a determinação da forma jurídica a partir da mercadoria. Crítica do Direito. São Paulo, n. 64, 2014. 
TERTULIAN, Nicolas. Lukács e o Stalinismo. Tradução Por Ronaldo Vielmi Fortes. In: Verinotio: 07 Revista On Line de Educação e Ciências Humanas, $n^{\circ}$ 11. Belo Horizonte: 2007 (disponível em <www. verinotio.org>)

. Lukács e seus contemporâneos. Tradução por Pedro Corgozinho. São Paulo: Perspectiva, 2016 (no prelo)

SARTORI, Vitor Bartoletti. A questão da crítica ao Direito à luz da obra madura de Lukács. In: TORRIGLIA, Patrícia Laura; MÜLLER, Ricardo Gaspar; LARA, Ricardo; ORTIGARA, Vidalcir (Org.). Ontologia e crítica do tempo presente. Florianópolis: Em debate, 2015 d.

Apontamentos sobre Estado, sociedade civil-burguesa e revolução em Marx. In: Verinotio: Revista On Line de Filosofia e Ciências Humanas, $n^{\circ} 14$. Belo Horizonte: 2012. (disponível em <www. verinotio.org>)

. Direito e socialismo? A atualidade da crítica de Marx e Lukács ao Direito. In: Direito e práxis n. 9. Rio de Janeiro: UFRJ, 2014 - Estética e política: equívocos e aproximações sobre a especificidade de cada esfera em Marx e Lukács. In: VEDDA, Miguel. VAISMAN, Ester. Arte, filosofia, sociedade. São Paulo: Intermeios, 2013.

. Lukács e a crítica ontológica ao Direito. São Paulo: Cortez, 2010.

Marx, marxismo e o terreno do Direito: um debate necessário. In: Verinotio: Revista Online de Filosofia e Ciências Humanas, n. 19. Belo Horizonte: 2015 b. (Disponível em <www.verinotio.org>)

. Moral, ética e Direito: Lukács e a teoria do Direito. In: Sapare Aude. Belo Horizonte: PUC MG, 2015 a.

. Teoria geral do Direito e o marxismo como crítica marxista ao Direito. In: Verinotio: Revista Online de Filosofia e Ciências Humanas, n. 19. Belo Horizonte: 2015 c. (Disponível em <www.verinotio.org>) 
SWEEZY, Paul. Socialismo. Tradução por Giasoni Rebuá e Mauricio Caminha de Lacerda. Rio de Janeiro: Zahar, 1963.

TERTULIAN, Nicolas. Lukács e o Stalinismo. Tradução Por Ronaldo Vielmi Fortes. In: Verinotio: 07 Revista On Line de Educação e Ciências Humanas, $n^{\circ}$ 11. Belo Horizonte: 2007 (disponível em <www. verinotio.org>)

. Sobre o método onto-genético em filosofia. Tradução por G. Vianna Konder. In: Revista Perspectiva. Florianópolis, v. 27, n. 2, 375-408, jul./dez. 2009.

VAISMAN, Ester. A ideologia e sua determinação ontológica. In: In: Verinotio: Revista On Line de Educação e Ciências Humanas, n 12. Belo Horizonte: 2010. (disponível em <www.verinotio.org>)

VARGA, Csaba. The place of Law in Lukács' world concept. Traduzido por Judir Petrányi e Sandor Eszenyi. Budapest: Szent Istvàn Tarsulat, 2012.

Recebido: 18/03/2016

Aceito: 30/05/2016 